\title{
Women Lawyers Blog for Workplace Equality: Blogging as a Feminist Legal Method
}

\author{
Alison I. Stein ${ }^{\dagger}$
}

ABSTRACT: Legal scholars and academic commentators have long written about the ways in which close-knit communities of people employ extralegal or nonlegal methods to structure conflict, resolve disputes, and advocate for their rights and interests. From cattle ranchers to diamond merchants to Third Wave feminists, scholars emphasize how groups of people opt out of the legal system and instead use personalized and informal methods of rights assertion and dispute resolution as a means of overcoming the ineffectiveness of statesponsored laws, or because they reject the law as a viable means of achieving change. Like these communities, a growing number of women lawyers have developed their own method of rights assertion and dispute resolution that does not involve turning to the legal system.

Despite the cottage industry of articles, books, and reports describing the role of gender in the legal profession, few, if any, writings have focused on what women lawyers are actually doing to address the challenges and grievances they face in the workplace, as well as to increase the number of women in leadership positions in the profession. Based on a detailed empirical analysis of women lawyers in law firms, this Article describes how a growing number of women lawyers have rejected the viability of the law as a means of personal advocacy and are instead using blogging - an alternative, informal and impersonal form of engagement - to advocate for their rights and interests in the workplace. One would expect that women lawyers, when confronted with unfair hiring practices, unequal pay, or unjust choices, would turn to the legal

\footnotetext{
† University of Pennsylvania Law School, J.D. expected 2009. University of Pennsylvania, B.A. 2003. For their generous feedback and advising, I thank Professors Anita Allen, Anne Kringel, Gideon Parchomovsky, Robert Solomon, and Amy Wax. In particular, I want to thank Professor Bridget Crawford for taking such an enthusiastic interest in my ideas, reading several drafts of this Article, and providing me with guidance and encouragement.

This Article is a tribute to the talented women bloggers who blog about their lives in the workplace. I want to thank all of the bloggers who were willing to take time out of their busy schedules to be interviewed and brave enough to share their personal stories, particularly Elizabeth Pederson, the visionary founder of Ms. JD. I also want to thank the lawyers and legal recniting staff I interviewed for being so candid about the challenges that remain in the profession, as well as Terra Gearhart-Serna, my editor at the Yale Journal of Law and Feminism. Finally, I am especially grateful to Professor Feldman, my mentor and good friend, for reading several drafts, and for offering his critical comments and wholehearted encouragement. I dedicate this Article to my mother, Emily Fine.
} 
system. They are legally trained and undoubtedly immersed in the law, and therefore one might presume that they are particularly attentive to legal rights and predisposed to think of personal grievances within a legal framework. However, these women recognize that the law does not necessarily favor their position or offer a fair conclusion. Thus, they are using the Internet-and, in particular, blogging-to resolve their disputes, address their personal grievances, challenge implicit male bias engrained in the profession, and share and obtain the information they need to become stronger bargainers in the workplace. By asking why women lawyers choose to blog about gender inequality in the profession, this Article reveals a great deal about the unique nature of the workplace challenges women lawyers face today.

INTRODUCTION 359



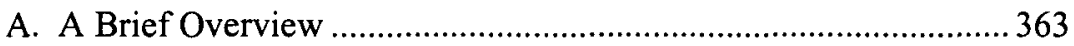



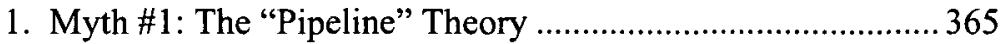

2. Myth \#2: "There Are Many More Men than Women in

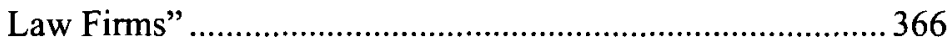



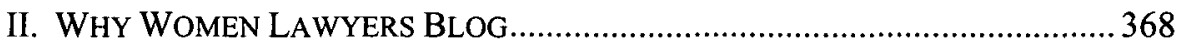

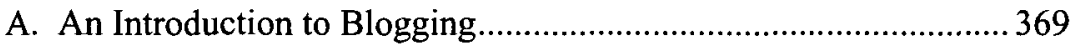

B. The "Limited-Means" View of the Legal System ......................... 372

C. Institutional Mindset: The "Maternal Wall" and the "All-or-

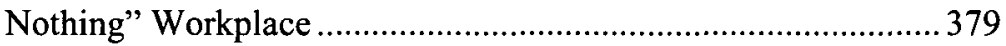

D. The Grievance Is Nonlegal in Character.......................................385

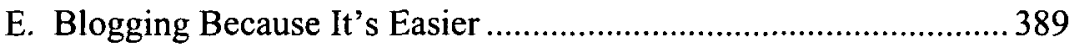

F. Critiques of Blogging ........................................................... 390

III. BLOGGING AS FEMINIST LEGAL METHOD ................................................ 392

A. Women's Experience and Consciousness Raising ....................... 393

B. An Ideological Commitment to Diversity of Voices and

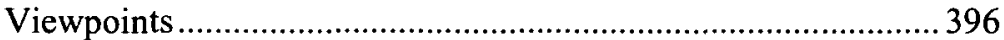

C. Double Binds and Dilemmas of Difference .................................. 398

D. Activism from the Ground Up ..................................................400

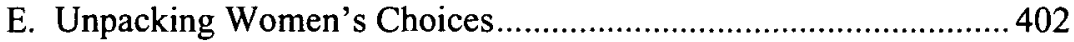

F. Blogging as a New Feminist Legal Method ...................................403

IV. THE IMPACT OF BLOGGING ON THE LEGAL PROFESSION........................... 404

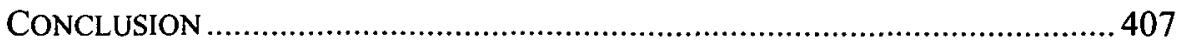


INTRODUCTION

The Internet in general -and specifically blogging - are great tools of expression and connection, and I have indeed seen women use blogging to advocate for themselves and the issues they are passionate about. There are so many groups bringing women together online to share resources, network, commiserate, develop strategies, and navigate the still male-dominated workplace. ... And it is a powerful tool for those looking to change laws that may not be working.

Legal scholars and academic commentators have long written about the ways in which close-knit communities of people employ extralegal or nonlegal methods to structure conflict, resolve disputes, and advocate for their rights and interests. $^{2}$ From cattle ranchers ${ }^{3}$ to diamond merchants ${ }^{4}$ to Third Wave feminists, ${ }^{5}$ scholars emphasize how groups of people opt out of the legal

1. E-mail from Arianna Huffington, Founder, Huffington Post, to author (Dec. 19, 2007, 19:35 EST) (on file with author).

2. See Eric A. Feldman, The Tuna Court: Law and Norms in the World's Premiere Fish Market, 94 CAL. L. REv. 313, $316 \mathrm{n} .8$ (2006) (describing the "provocative thesis" suggested by all of these writings as the idea that "informal norms, rather than state-created law will order the relationships among closeknit groups").

3. See Robert C. Ellickson, Order Without law: How Neighbors Settle Disputes (1991) (exploring how disputes within a tight-knit community of California cattle-ranchers are resolved without recourse to the law or to courts).

4. See Lisa Bernstein, Opting Out of the Legal System: Extralegal Contractual Relations in the Diamond Industry, 21 J. LEGAL STUD. 115 (1992) (describing how the members of the diamond industry have "systematically rejected state-created law ... [and instead] developed an elaborate, internal set of rules ... to handle disputes among industry members"); see also Barak D. Richman, How Community Institutions Create Economic Advantage: Jewish Diamond Merchants in New York, 31 LAW \& Soc. INQUIRY 383, 414 (2006) ("Jewish predominance in the diamond industry is explained by the community's ability to enforce contracts that are unenforceable for other merchants... [leading to] a system of reliable contractual enforcement that permits sales on credit and leads to a rejection of public courts.").

5. See Bridget J. Crawford, Towards a Third Wave Feminist Legal Theory: Young Women, Pornography and the Praxis of Pleasure, $14 \mathrm{MICH}$. J. GENDER \& L. 99, 102, 105 (2007) (describing how, "[n]otwithstanding their interest in social, political and economic-justice issues, Third Wave feminists do not write from an explicitly legal perspective," and suggesting that this extralegal approach to Third Wave activism may "set the stage for the development of a vibrant Third Wave feminist legal theory"). There are many definitions of Third Wave feminism, and many ideas about who or what kind of person constitutes a Third Wave feminist (or "Third Waver"). In the most literal and formal sense, the phrase was first coined by Rebecca Walker in an angry piece she drafted about the Senate Judiciary Committee's treatment of Anita Hill's testimony during Clarence Thomas's Supreme Court confirmation hearings. In her piece, published by Ms. magazine, the then twenty-two-year-old Walker argued that the Senate hearings "were not about determining whether or not Clarence Thomas did in fact harass Anita Hill. They were about checking and redefining the extent of women's credibility and power." Rebecca Walker, Becoming the Third Wave, Ms., Jan.-Feb. 1992, at 39, 39 reprinted in Ms., Spring 2002, at 86, 86. Walker described Anita Hill's "dismissal" as a spur to "political power." Id. at 87. Throughout the piece, she encouraged women of her generation: "Do not vote for [men] unless they work for us. Do not have sex with them, do not break bread with them, do not nurture them if they don't prioritize our freedom to control our bodies and our lives." Id. She concluded by declaring, "I am not a post-feminism feminist. I am the Third Wave." Id. Feminist scholars have since considered Walker's article "the first to envision and call for a vibrant active third wave of feminism as a generation-based movement." Crawford, supra, at 108 (internal quotations omitted). Today, some define the Third Wave by age and generation. For example, Jennifer Baumgardner and Amy Richards define Third Wave as "the core mass of the current women's movement in their late teens through their thirties." JENNIFER 
system-and instead use personalized and informal methods of rights assertion-as a means of "overcom[ing] the ineffectiveness" of state-sponsored laws, ${ }^{6}$ or because they reject the law as a "viable means of achieving change."7 Like cattle ranchers and diamond traders, a growing number of women lawyers have developed their own method of rights assertion and conflict resolution that does not involve turning to the legal system.

For over a century, the unique and unparalleled challenges facing women in the legal profession have provided journalists, writers, and scholars interested in feminist issues with an abundance of rich material. In 1872, Myra Bradwell was denied membership to the Illinois State Bar, with one concurring Justice stating that " $[\mathrm{t}] \mathrm{he}$ natural and proper timidity and delicacy which belongs to the female sex evidently unfits it for many of the occupations of civil life... [t] he paramount destiny and mission of woman are to fulfil the noble and benign offices of wife and mother." ${ }^{\prime 8}$ Since Bradwell's devastating day in court, there have been various notable writings about the obstacles that hinder women's advancement in the legal profession. In 1886, a group of women lawyers and law students formed the Equity Club, a correspondence organization through which they discussed the challenge of advancing in the nearly all-male legal profession. ${ }^{9}$

In 1989, feminist scholar Leslie Bender boldly declared that the legal profession "has been constructed by men to reinforce and reward their gendered male characteristics ... [while female characteristics] which [are] not part of the male gender culture, [are] excluded and perceived as inappropriate or interruptive of the important functions of professional work." 10 In 1993, Mona Harrington published a landmark study of interviews with over 100 female graduates from Harvard Law School, whose experiences created a

BaUMgardner \& AMY RichaRd, MANIFESTA: Young WOMEN, FEMINISM, AND THE FUTURE 401 (2000). Likewise, Wikipedia defines Third Wave feminism as "several diverse strains of feminist activity and study beginning in the early 1990s." Wikipedia, Third Wave Feminism, http://en.wikipedia. org/wiki/Third_wave_feminism (last visited Sept. 17, 2008). Wikipedia also notes that many define Third Wave feminism by its relation to Second Wave feminism. "The movement arose as a response to perceived failures and backlash against initiatives and movements created by second-wave feminism." Id. When asked, I tend to describe Third Wavers not only by age or generation, but also as those working on the implementation and protection of the laws passed by the Second Wave, attempting to transform these laws into an everyday reality of equality for women.

6. Richman, supra note 4, at 385 .

7. Crawford, supra note 5 , at 160 (suggesting that for women in the twenty-first century, who have knowledge of setbacks of the women's movement, such as the failure of the Equal Rights Amendment and the lower level of scrutiny for gender discrimination, "the law's limited ability to affect social change is obvious").

8. Bradwell v. Illinois, 83 U.S. 130, 141 (1872) (Bradley, J., concurring).

9. See VIRGINIA G. DRACHMAN, WOMEN LAWYERS AND THE ORIGINS OF PROFESSIONAL IDENTITY IN AMERICA: THE LETTERS OF THE EQUITY CLUB 1887-1890 (1993); see also VIRGINIA G. DRACHMAN, SISTERS IN LAW: WOMEN LAWYERS IN MODERN AMERICAN HISTORY 67 (1998) (describing the role of the Equity Club in helping women lawyers to connect with each other and explore the often problematic intersection of their profession and their gender). (1989).

10. Leslie Bender, Sex Discrimination or Gender Inequality?, 57 FORDHAM L. REV. 941, 949 
deeply disturbing narrative of a "'men's club' atmosphere, sexual harassment, focus on billable hours to the exclusion of family life, and current irreconcilable differences between women in the legal profession." ${ }^{11}$ Recently, Dean Elena Kagan of Harvard Law School described a "cottage industry in reports exposing stark differences in the career paths of men and women [in the legal profession]." 12

Despite this "cottage industry" of articles, books, and reports describing the role of gender in the legal profession, few, if any, empirical investigations have focused on what women lawyers are actually doing to address the challenges and grievances they face in the workplace and to increase the proportion of women in leadership positions in the profession. ${ }^{13}$ Based on a detailed, empirical analysis of women lawyers in law firms, this Article argues that, similar to Ellickson's cattle ranchers and Bernstein's diamond traders, a growing number of women lawyers, particularly women lawyers in law firms, have developed their own methods of rights assertion. They have rejected the viability of the law as a means of personal advocacy and are instead using blogging-an alternative, informal, and often anonymous form of engagement-to advocate for their rights and interests in the workplace. One would expect that women lawyers, when confronted with unfair hiring practices, unequal pay, or unjust choices, would turn to the legal system. They are legally trained and undoubtedly immersed in the law, and therefore one might presume that they are particularly attentive to legal rights and predisposed to think of personal grievances within a legal framework.

11. MONA HARRINGTON, WOMEN LAWYERS: REWRITING THE RULES (1994) (language from description on back cover of book).

12. See Elena Kagan, Dean, Harvard Law School, Remarks on the Status of Women in the Law, Leslie H. Arps Memorial Lecture at the Association of the Bar of the City of New York (Nov. 17, 2005), available at http://www.law.harvard.edu/about/dean/women-in-law.html [hereinafter Dean Kagan Remarks]; see also RONIT DINOVETZER ET AL., NALP FOUND. FOR LAW CAREER RESEARCH \& EDUC. \& AM. BAR FOUND., AFTER THE JD: FIRST RESULTS OF A NATIONAL STUDY OF LEGAL CAREERS (2004), available at http://www.nalpfoundation.org/webmodules/articles/articlefiles/87-After_JD_2004_Web. pdf [hereinafter AFTER THE JD]. The After the JD Project, sponsored by NALP and the American Bar Association, is a longitudinal study tracking the professional lives of more than 5,000 lawyers during their first ten years after law school. The study began tracking law school graduates in 2002, and the first series of results were released in 2004. Since 2004, there have been shorter monographs released that provide updated data on specific topics like women in the profession and paying off law school debt. Updated data for the entire survey will likely be released in 2008 .

13. The scholarship on women in the legal profession can be divided into three categories: scholarship documenting the lack of women's progress in the legal profession, scholarship offering explanations as to why women are not advancing in the legal profession, and scholarship suggesting solutions and strategies for how women can achieve gender equity in the profession. None of these three types of writing looks at what women lawyers are actually doing to advance their leadership and expand their opportunities in their profession. See, e.g., LAUREN STILLER RIKLEEN, ENDING THE GAUNTLET: REMOVING BARRIERS TO WOMEN'S SUCCESS IN THE LAW (2006) (focusing on the challenges facing women in the practice of law in law firms and outlining a set of recommendations for change); see also Judith S. Kaye \& Anne C. Reddy, The Progress of Women Lawyers at Big Firms: Steadied or Simply Studied, 76 FORDHAM L. REV. 1941, 1943-44 (2008) (looking at "the profile of women in the profession" and whether there are areas where "changes ... are nevertheless contributing to the ultimate goal of gender equality"). 
Nonetheless, a growing number of women lawyers are using the Internet - and, in particular, blogging-to resolve their disputes, address their personal grievances, challenge implicit male bias engrained in the profession, and share and obtain the information they need to become stronger bargainers in the workplace. For a variety of reasons, these women have found it effective and rewarding to use blogging - instead of traditional legal or legislative avenuesto advocate for their own personal rights in the workplace and to "openly challenge[] the rules under which success in the legal arena is defined and the structures that reinforce men's dominance in law."14

Part I provides both a brief overview of the status of women in the legal profession and a concise history and background of the relevant blogs. Part II analyzes blog entries and draws from several interviews with women lawyers and bloggers to suggest four reasons why women lawyers might turn to blogging instead of the law. Asking why women lawyers have chosen to blog about gender and the legal profession, rather than to address these issues legally, reveals a great deal about the unique nature of workplace challenges women lawyers face today. It is important to note that this Article intentionally focuses on young women lawyers who are working in law firms, despite the fact that women from all areas of the profession-including women law students-are currently engaged in blogging. This focus is largely for two reasons. First, as this Article explains, the gender disparity is most visible in law firms because the hierarchical structure of law firms is clear. "The rate at which women versus men advance in a law firm is transparent and obvious, whereas in other legal workplaces, there is a flat hierarchical structure and you don't necessarily know how gender is having an impact."15 Second, this Article is interested in younger women by design, as it explores ways in which blogging is a new, modern method of rights assertion utilized primarily by younger generations. Because law firms are the single largest recipient of recent law school graduates, ${ }^{16}$ the younger women blogging about the legal profession are in large part employed by law firms. Part III of the Article problematizes the method of blogging and examines it within the context of feminist legal theory. Specifically, it seeks to place blogging within the framework of five "opening moves" or methods that feminist scholars have developed to "place women at the center rather than the margins of the study of

14. Cynthia Grant Bowman, Women and the Legal Profession, in FEMINIST JURISPRUDENCE, WOMEN AND THE LAW: CRITICAL ESSAYS, RESEARCH AGENDA, AND BiblogRAPHY 625, 639 (Betty Taylor, Sharon Rush \& Robert J. Munro eds., 1999).

15. Interview with Elizabeth Pederson, Founder, Ms. JD, in Philadelphia, Pa. (Aug. 29, 2008).

16. NALP reports that $55.5 \%$ of the class of 2007 obtained employment in the private practice sector. NALP, MARKET FOR NEW LAW SCHOOL GRADUATES AT HIGHEST IN 20 YEARS, APPROACHING 92\%, at 1 (2008), available at http://www.nalp.org/assets/1181_07selectedfindings.pdf. This figure has fluctuated between $55 \%$ and $58 \%$ since 1993 . Id. at 3 . The next largest category of employment is business, which captures $14.1 \%$ of recent graduates. Id. at 1 . 
law"17 and "document[] the experiences of gender."18 The Part then argues that blogging is a new feminist legal method. Finally, Part IV demonstrates how legal blogging has actually created change in the profession and continues to hold great promise as a means of achieving gender equality, expanding women's choices, and redefining notions of success in the legal profession and perhaps in the workplace more generally.

\section{THE STATUS OF WOMEN IN THE LEgAL PROFESSION}

\section{A. A Brief Overview}

In 1873, the United States Supreme Court held that the right for a woman to practice law was not a privilege or immunity of a citizen of the United States within the meaning of the Fourteenth Amendment. ${ }^{19}$ It was not until fifty years later, in 1924, that a Wall Street law firm hired what is believed to be its first female associate, and it took another eighteen years for the firm to make that woman a partner. ${ }^{20}$ Between 1970 and 1988 , the percentage of wumen lawyers rose from $3 \%$ to $20 \%{ }^{21}$ By 1988 , while $33 \%$ of associates at the largest 250 law firms were women, women made up fewer than $8 \%$ of the partner pool. ${ }^{22}$ It is important to note that at that time, there had been "enough women graduating from law school for a long enough time to make a substantial dent in these figures." ${ }^{23}$ Just a few years later, a 1993 survey of nearly one thousand lawyers made headlines when it revealed that $51 \%$ of women lawyers had been sexually

17. Martha Chamallas, Introduction to Feminist Legal Theory 4, 13 (2003) (outlining five "moves" or "theoretical tools that feminist legal scholars have found useful to critique legal doctrines and categories in each of the ... stages of feminist legal theory" (emphasis omitted)).

18. NANCY LEVIT \& ROBERT R.M. VERCHICK, FEMINIST LEGAL THEORY 45 (2006) (“[F]eminist legal methodology focuses on the tools of how to practice feminist legal thinking and the ways of documenting the experiences of gender.").

19. Bradwell v. Illinois, 83 U.S. 130, 139 (1872).

20. See Karen B. Morello, The Invisible Bar: The Woman Lawyer in America, 1638 to THE PRESENT 201-02 (1986). The well-known firm of Sullivan \& Cromwell did not hire its first woman associate until 1930, and did not name its first woman partner until more than fifty years later, in 1982. Id. at 197.

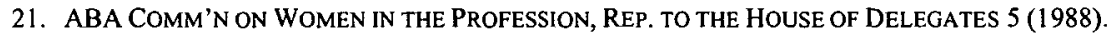

22. Id. At the time this report was released, some tried to explain these figures away by "the coincidence of women's arrival upon the scene with the years of belt-tightening and bottom lining in law firms." Bowman, supra note 14, at 634 (discussing Abbie W. Thomer, Gender and the Profession: The Search for Equal Access, 4 GEO. J. LEGAL ETHICS 81, 99 (1990)). However, a study looking at women up for promotion found that women were "half as likely as men to become partner even in those years of relative plenty; when controlling for academic distinction, prestige of law school, and productivity, the probability of partnership was $38.6 \%$ for men and $17.9 \%$ for women." $I d$. at $634-35$ (citing Stephen J. Spur, Sex Discrimination in the Legal Profession: A Study of Promotion, 43 INDUS. \& LAB. REL. REV. 406, 409 (1990)).

23. See Bowman, supra note 14, at 634 (citing ABA COMM'N ON WOMEN IN THE PROFESSION, supra note 21 ). For a larger discussion of the "pipeline" myth, see infra Part I.B.1. 
harassed at some point in their career. ${ }^{24}$ Despite the statistics and reports of the 1980s and 1990s, commentators argued that the lack of women in leadership positions and the treatment of women in law firms was simply a result of the fact that women had only recently entered the profession. It would take time, the argument went, to build a pipeline that would lead to equal numbers of men and women in positions of leadership. Likewise, the profession simply needed time to get used to the idea of women as equals and to develop and foster a culture of gender equity. ${ }^{25}$

Yet, while women comprise over half of all law school students ${ }^{26}$ and $49 \%$ of first- and second-year associates in law firms today, ${ }^{27}$ they account for only $16 \%$ of equity partners, ${ }^{28} 15 \%$ of firm governance committee membership, ${ }^{29}$ and $15 \%$ of general counsels of Fortune 500 companies. $^{30}$ To put these numbers in historical perspective, in 1988 , only $8 \%$ of law firm partners were women, but this can perhaps be attributed to the fact that associate entry-level classes were only $33 \%$ female as well as the fact that "women did not enter firms in significant numbers until the mid-1970s." ${ }^{\prime 31}$ In 1992, women had risen to comprise $50 \%$ of their associate classes and $15 \%$ of partners, a clear improvement. ${ }^{32}$ However, today, the progress has stagnated. Almost two decades later, while associate entry-level classes remain 50\% female, women still account for only $16 \%$ of equity partners. ${ }^{33}$ Despite the lasting gender parity of associates, the number of women occupying leadership positions in the profession has clearly not risen concomitantly. Today, women constitute only $23 \%$ of federal district court and circuit court judges, $19 \%$ of law school deans, and $25 \%$ of tenured law school professors. ${ }^{34}$ The United States Supreme Court has had only two female Justices, the United States has had only one female U.S. Attorney General, and there has yet to be a female Solicitor General.

24. Mark S. Kende, Shattering the Glass Ceiling: A Legal Theory for Attacking Discrimination Against Women Partners, 46 HASTINGS L.J. 17, 20 (1994).

25. See Dean Kagan Remarks, supra note 12 (describing what she terms "the pipeline issue"-the assumption that, over time, women will gain equal numbers in positions of leadership in the legal profession).

26. Id.

27. National association of WOMEn Lawyers, National SURVEy on Retention and PROMOTION OF WOMEN IN LAW FIRMS 4 (2007), available at http://www.abanet.org/nawl/docs/ FINAL_survey_report_11-14-07.pdf. [hereinafter NAWL SURVEY]. The survey was sent to the 200 largest law firms in the country.

28. Id. at 2.

29. Id. at 3 .

30. Dean Kagan Remarks, supra note 12.

31. ABA COMM'N ON WOMEN IN THE PROFESSION, supra note 21.

32. See Kaye \& Reddy, supra note 13, at 1946.

33. NAWL SURVEY, supra note 27 , at 3.

34. Dean Kagan Remarks, supra note 12. 


\section{B. Mistaken Assumptions}

Often, when people first become aware of the aforementioned statistics, they are deeply resistant to interpreting these numbers as evidence of gender disparity in the legal profession. While they admit that evidence of fewer women in leadership positions is irrefutable, they frequently suggest three theories as to why this is the case. These theories attempt to place the blame on something other than overt discrimination, subtle discrimination, or even institutional barriers to women's advancement. ${ }^{35}$ These three theories-the "pipeline" theory, the "there are many more men than women in law firms" theory, and the "opting out" theory-are largely misguided, as are the assumptions behind them.

\section{Myth \#1: The "Pipeline" Theory}

The most common theory as to why women have not achieved equality with men in the legal profession is the "pipeline" theory-the idea that "partnerships [will] come to mirror the associate pool" when enough years have passed when there have been equal numbers of female and male associates. ${ }^{36}$ This theory mistakenly assumes that women have only recently comprised a near-majority of their law school classes. On the contrary, by the fall of 1980 , women already constituted an average of $34 \%$ of entering law school classes. ${ }^{37}$ Since 1992, almost half of law school graduates have been women. ${ }^{38}$ Yet, since 1992, the number of female law firm partners has remained at $15 \%$ or $16 \% .{ }^{39}$ In 2001, the New York Times announced that women were likely to reach the majority of those enrolling in law school. ${ }^{40}$ Women had accounted for $49.4 \%$ of all students who began law school in the fall of 2000 , and the article predicted that they would surpass $50 \%$ for the fall 2001 entering class. ${ }^{41}$ However, the

35. Discrimination has become an increasingly loaded term, and merits clarification here. In the few instances where I use the term "discrimination" in this Article, it is only because the term was used by the bloggers whom I interviewed. The bloggers generally classified obstacles they faced in the workplace as "discrimination" when they felt that an employer, colleague, or classmate intentionally treated them as inferior because they were women. While it is important to note that gender equity jurisprudence has a far more complex definition of what constitutes gender "discrimination"- - one that is often dependent upon the context of the alleged discrimination and the jurisdiction-that discussion is beyond the scope of this Article.

36. Dean Kagan Remarks, supra note 12.

37. N. William Hines, Ten Major Changes in Legal Education Over the Past 25 Years, AALSNEWS (Assoc. of Am. Law Sch.), Nov. 2005, at 1, 4, available at http://www.aals.org/documents/aals_ newsletter_nov05.pdf.

38. See Kaye \& Reddy, supra note 13, at 1946 n.13.

39. See NAWL SURVEY, supra note 27.

40. Jonathan D. Glater, Women are Close to Being Majority of Law Students, N.Y. TIMES, Mar. 26, 2001 , at A1.

41. Id. Specifically, in the fall of 2000 women were $46 \%$ of the entering class at Harvard Law School, $44 \%$ at Stanford Law School, $51 \%$ at Columbia Law School, and $50 \%$ at New York University School of Law. Id. 
number of women law students remained at $49 \%$ through 2002 , and hovered around $47 \%$ in $2007 .{ }^{42}$ On average, it takes seven to eight years to make partner in a law firm. ${ }^{43}$ Thus, if women and men were equally likely to make partner, women should have reached parity with men in partnership numbers by $2008 .{ }^{44}$ In other words, the "pipeline" theory is false. ${ }^{45}$

\section{Myth \#2: "There Are Many More Men than Women in Law Firms"}

When the pipeline theory is refuted, people suggest yet another explanation as to why women are not advancing at the same rate as men into leadership positions: The "male-dominated law firms" theory. ${ }^{46}$ This is the idea that while women begin their careers at law firms after graduating from law school, they leave firms earlier than men to pursue other sorts of legal or nonlegal work. However, women today represent $49 \%$ of first- and second-year associates, and this percentage does not drop in any significant way as the years pass. In fact, women comprise $43 \%$ of seventh-year associates, and partnership decisions are most often made in the seventh year. ${ }^{47}$

\section{Myth \#3: The "Opting-Out" Theory}

The third and perhaps most contentious theory suggests that women lawyers are "opting out" of the profession-either completely or through working reduced hours - to raise children and "manage" their families and households. Given the fact that, on average, working mothers only take 2.1 years away from the workplace, this theory should immediately elicit questions. $^{48}$ The phrase "opting out" was coined by New York Times reporter Lisa Belkin, who, in 2003, described a "supposed revolution" in which "some of the nation's most highly educated young women plan to put aside their careers once they have children ... decid[ing], in essence, that they can't-or don't want to- 'have it all.",49 Acknowledging that she was writing about

42. Hines, supra note 37; Leigh Jones, Fewer Women are Seeking Law Degrees, NAT'L L.J., Oct. 1, 2007 , at 1 .

43. See, e.g., Leigh Jones, New-Partner Growth Takes a Hit, NAT'L L.J., Feb. 11, 2008, at 1.

44. Since women comprised $49.4 \%$ of their law school classes in 2001 , there should have been parity in partnership decisions seven years later, in 2008.

45. Not only has the "pipeline" theory been undermined, but it is now referred to as the "leaky pipeline"- the idea that "equal percentages of female and male first-year associates do not translate, ten years later, into equal percentages in firm partnership ranks." See Kaye \& Reddy, supra note 13, at 1942-43.

46. This theory was suggested to the author by seven people who read her piece.

47. See NAWL SURVEY, supra note 27 , at 4.

48. JOAN C. Williams, Jessica MANVEll \& StePhanie Bornstein, CTR. FOR WORKLifE LaW,

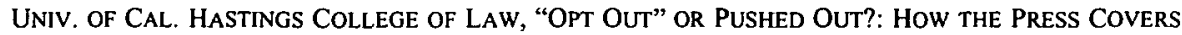
WORK/FAMILY CONFLICT 23 (2006).

49. Dean Kagan Remarks, supra note 12 (describing Lisa Belkin, The Opt-Out Revolution, N.Y. TiMES, Oct. 26, 2003, § 6 (Magazine), at SM44). 
"elite, successful women who can afford real choices" (for example, women lawyers), Belkin argued that women were discovering that the prizes of money and power were ones they "didn't really want.",50

Joan Williams, one of the nation's preeminent scholars on women in the workplace, describes the enduring (and, in the opinion of many, negative) impact of Belkin's piece on women's advancement in the workplace: "Belkin's success in naming and framing reshaped and refreshed a well-entrenched story line: that women are returning home as a matter of choice, the result of an internal psychological or biological 'pull' rather than a workplace 'push." ${ }^{51}$ In other words, Williams suggests that Belkin's piece ignores the fact that women are not "opting out" but being "pushed out." W2 Williams's suggestion is supported by a recent study that found that $86 \%$ of women cite workplace "pushes" (including inflexible jobs, lack of good, affordable childcare, and lack of paid leave to take care of sick children) as the key reason for their decision to leave. ${ }^{53}$

In a study by Catalyst, a women's issues think tank, law school graduates cited "personal and family responsibilities" as the "single largest barrier" to the advancement of women lawyers. ${ }^{54}$ Describing family responsibilities as a "barrier" strongly suggests that women are not "opting out," but instead being pushed out by inflexible workplace policies. Confirming this point, a recent study of women in law, business, medicine, and academia found that $93 \%$ of

50. Belkin, supra note 49.

51. WILliamS, MANVELL \& BORNSTEN, supra note 48 , at 5.

52. Id. at 3. What's worse, Williams argues, is that Belkin's article spurred an outpouring of writings discussing the phenomenon under the same misconception, "reinforc[ing] the Opt-Out narrative." Id. at 5; see, e.g., Claudia Deutsch, Behind the Exodus of Executive Women: Boredom, N.Y. TIMES, May 1, 2005, at B4 (arguing that women leaving the workplace "has less to do with discrimination in the corporate suite or pressures at home than with frustration and boredom on the job"); Jane Gross, Forget the Career. My Parents Need Me at Home., N.Y. TimEs, Nov. 24, 2005, at Al (noting that, among women who left the workplace, one of the most common reasons cited was caregiving, and that these women "may see leaving a high-powered career as an opportunity, not a sacrifice"); Louise Story, Many Women at Elite Colleges Set Career Path to Motherhood, N.Y. TIMES, Sept. 20, 2005, at Al ("Many women at the nation's most elite colleges say they have already decided that they will put aside their careers in favor of raising children"). Some have gone so far as to describe Belkin's article as "The New York Times' bizarre and suspiciously predetermined editorial effort to talk women out of working ...." Bonnie Erbe, Women 'Opting Out' of Work? Not in U.S., DesERET News, Mar. 12, 2006, at A5.

53. WILLIAMS, MANVELL \& BORNSTEIN, supra note 48 , at 2 . There are examples of workplaces within the legal profession where family life is made a priority by the employer. See, e.g., Deborah Epstein Henry, Stepping into Your Shoes: It's Time for Job Shares in Law Firms, DIVERSITY \& BAR, July-Aug. 2007, at 16, 17 (proposing that law firms adopt "job share" programs-a model enabling two attorneys to share one position-because the "model has worked well for in-house legal department, not-for-profit, and government lawyers as well as numerous other professionals"). Epstein Henry explains that in these other contexts, a job share "functions as if one member physically stepped into the other's shoes midweek, taking over the workload," and the arrangement has worked so well because it "minimizes many of the reduced-hour pitfalls, including continued schedule unpredictability; the need to always be available; working more hours than were negotiated... [the] difficulty delineating lines between work and home; and overpaying for childcare." Id. at 17.

54. Dean Kagan Remarks, supra note 12. 
women who have left the workforce want to return. ${ }^{55}$ Similarly, After the JD found that "women are far more dissatisfied than men with every aspect of their jobs except the work itself" and these obstacles lead women to leave the workplace at higher rates than their male colleagues. ${ }^{56}$ This finding is not surprising. The recent NAWL survey found a significant pay gap between men and women in the legal profession. ${ }^{57}$ While male and female associates generally earn about the same salary, "male of counsels earn roughly $\$ 20,000$ more than females, male non-equity partners earn roughly $\$ 27,000$ more than females, and male equity partners earn almost $\$ 90,000$ more than female equity partners," 58 accounting for number of hours worked. Inequality can, of course, lead to dissatisfaction with one's job. As Leslie Bender declared in 1989, the legal profession "has been constructed by men to reinforce and reward their gendered male characteristics." 59

Once the "pipeline," "male-dominated law firms," and "opt-out" theories are discredited, it becomes clear that women have not advanced at the same rate as men in the legal profession. To discover and counter whatever role gender might play in the progression of their legal careers, many women lawyers have turned to blogging.

\section{WHY WOMEN LAWYERS BLOG}

Many of the workplace grievances that women lawyers face could, theoretically, be addressed (and at times, have been addressed) through the legal system. ${ }^{60}$ Turning to the legal system, however, seems to be the exception

55. Sylvia Ann Hewlett \& Carolyn Buck Luce, Off-Ramps and On-Ramps: Keeping Talented Women on the Road To Success, HARV. BUS. REV., Mar. 2005, at 43, 45. The average amount of time professional women spend "off-ramp" is only 2.2 years. Id. at 46 .

56. Dean Kagan Remarks, supra note 12; see also AFTER THE JD, supra note 12, at 58 (discussing “three ... dimensions of satisfaction where women's ratings were significantly lower than those of men: namely job setting, social index of work, and the power track").

57. See NAWL SURVEY, supra note 27 , at 8-9.

58. Id. at 9 .

59. Bender, supra note 10 , at 949 . Within the legal profession there are, of course, workplaces that are less biased towards gendered male characteristics. Elizabeth Pederson stated during her interview that many law firms and government legal offices have "progressive policies." Interview with Elizabeth Pederson, supra note 15 . She explained that "[t]his is important because no matter how much we progress in the workplace, the reality is that inside the home, most women today continue to have more responsibility than men. Measuring success only by hours will therefore disadvantage women." Id. Pointing to government offices such as District Attorney's offices, Pederson describes places where "women and men both work more reasonable hours and there is generous maternity and paternity leave." Id. Pederson also notes that many law firms have adopted progressive policies, but because the industry "remains client-driven and service-oriented," firms cannot move away from the billable hour model, even if their intention is to do so. Id.

60. See Trezza v. Hartford, Inc., No. 98 Civ. 2205, 1998 WL 912101 (S.D.N.Y. Dec. 30, 1998). The WorkLife Law Center summarizes this case as follows:

An attorney and mother of two young children claimed that her employer failed to consider her for a promotion because she was a mother. Despite her consistently excellent job evaluations, the higher position was offered to less qualified men with children, who turned it down, and to a woman without children. The attorney was told 
rather than the norm. Asking why women lawyers choose to blog about gender inequality in the profession as opposed to addressing it legally or legislatively reveals a great deal about the types of workplace challenges women lawyers face today. This in turn can help explain why the number of women lawyers in leadership positions remains as low as it was twenty years ago. The following section suggests four possible instances in which women lawyers may turn to blogging as a means of advocating for their rights and interests in the workplace: 1) when there is a recognition of the current law's limited ability to vindicate rights; 2) when the grievance is born out of institutional bias and mindset; 3) when the grievance is nonlegal in character; and 4) when there is an appreciation for the anonymity of blogging and its reputation-protecting benefits. Whichever reason draws women to blogging, this section demonstrates that, in all the examples cited, blogging becomes a conduit for change in the blogger's workplace life. The change can take the more amorphous form of benefits resulting from networking, activism, venting, reassurance, or support, or the more concrete form of actual, quantifiable change in the blogger's position in her workplace. The section begins by providing a brief introduction to the movement of blogging.

\section{A. An Introduction to Blogging}

Technorati, the largest database tracking online news sources, is currently tracking 112.8 million blogs in the global blogosphere. ${ }^{61}$ Within this larger blogosphere, there is a burgeoning movement of female bloggers. A search for "feminist blogs" on Alexa, an Internet research company, produced about 398,000 blogs. $^{62}$ Another recent estimate put the number of "feminist blogs" at 240,000 and described "an explosion of feminist blogs, including many that

\footnotetext{
that she was not considered for the promotion because it would require extensive traveling, in which she presumably would not be interested because of her family. In addition, the senior vice-president of her company complained to her about the "incompetence and laziness of women who are also working mothers." He also noted that women are not good planners, especially women with kids. The general counsel of the legal department in which she worked stated that working mothers cannot be both good mothers and good workers, saying, "I don't see how you can do either job well." The court also considered that only seven of the forty-six managing attorneys were females and that none of them were mothers with school age children, whereas many of the male managing attorneys were fathers. The employer's motion to dismiss was denied and the case later settled.
}

Ctr. for WorkLife Law, Univ. of Cal. Hastings Coll. of Law, Recent and Noteworthy FRD [Family Responsibility Discrimination] Cases, http://www.worklifelaw.org/RecentCases.html (last visited Nov. $30,2008)$.

61. See Technorati Media, About, http://www.technorati.com/about/ (last visited Sept. 17, 2008). According to their data, "[b]loggers update their blogs to the tune of over 1.6 million posts per day, or over 18 updates a second." Id.

62. Alexa: The Web Information Company, Results for Feminist Blogs, http://www.alexa.com/ search?q=feminist\%20blogs (last visited Sept. 17, 2008). 
have a highly professional edge, and a large, loyal readership." ${ }^{, 3}$ In her description of young women's activism, Professor Bridget Crawford lists "harnessing and interpreting media",64 as one of the principal methodologies employed by Third Wave feminists, and describes how "third wave feminists use popular formats ... to disseminate their message." author and blogger Jessica Valenti describes how women are now using blogs, which "build[] a community that you can't get anywhere else."66

At the time that she founded Ms. JD, a blog designed specifically for women in the legal profession, Elizabeth Pederson was a Stanford law student who regularly found herself involved in conversations with female classmates, in which they would make "informal observations about the ways in which gender was affecting [their] experiences." ${ }^{, 67}$ Such observations included the fact that women did not speak up in class as often as men did, that more men than women garnered top law school honors such as positions on the law review executive board and Order of the Coif recognition, ${ }^{68}$ and that, in general, "people in all of the top positions throughout the law school were men.",69 "There was a pervasive feeling among us that gender was affecting our experiences in law school, and we wondered how that would carry over to our experiences when we entered the workplace." ${ }^{, 70}$ Pederson and her classmates wanted a larger forum to talk about these issues: ${ }^{71}$

Because it's not always clear what women lawyers are up against, we wanted to reach out to other women to explore what we could do to support each other in achieving success in the profession. Starting a blog allowed us to share personal stories, get advice from others, and make sure [that] all women have information and mentorship readily available to promote their interests as they become lawyers. In thinking about how to bring together a diverse group of people with many different perspectives, we realized that a blog was the best way to achieve this goal. ${ }^{72}$

Concerned by "the rates at which women 'opt out' of the legal profession, the lack of representation of women in the highest courts and at the highest

63. Kira Cochrane, The Third Wave-At a Computer Near You, GuARDIAN (London), Mar. 31, 2006 , at 18 .

64. Crawford, supra note 5 , at 104.

65. Id. at 127. For a definition of Third Wave feminism, see supra note 5.

66. Jessica VAlenti, Full Frontal FEMINISM: A Young WoMAN's Guide to Why FEMINISM MATTERS 180 (2007).

67. Telephone Interview with Elizabeth Pederson, Founder, Ms. JD (Oct. 31, 2007).

68. Id. The Order of the Coif is "an honorary scholastic society the purpose of which is to encourage excellence in legal education by fostering a spirit of careful study, recognizing those who as law students attained a high grade of scholarship." The Order of the Coif, http:/www.orderofthecoif.org (last visited Sept. 17, 2008).

69. Telephone Interview with Elizabeth Pederson, supra note 67.

70. Id.

71. $I d$.

72. Id. 
echelons of the legal community, and the role of gender in the progression of many women's legal careers," a group of female law students from twelve of the nation's top law schools came together under Pederson's leadership for a conference titled "Ms. JD: Changing the Face of the Legal Profession." During this March 2006 weekend, Pederson and dozens of other female law students officially launched the Ms. JD blog. Today, Ms. JD's goal is "to improve the experiences of women in law school and the legal profession... [and] to give voice to why it matters that women continue to face . . . barriers." "74 The blog exists to "promote and expand the success of women lawyers everywhere," 75 and works towards this goal by fostering "dialogue about women in the law," creating "a space for conversations about these complex issues and their possible solutions," and providing "networking opportunities, critical analysis of relevant news, and thoughtful discussions for women about their chosen fields of law." ${ }^{, 76}$ The content on Ms. JD is organized into a variety of "forums" where registered bloggers can post comments and the public can respond. ${ }^{77} \mathrm{Ms}$. JD also offers job opportunity boards and private networking forums for internal discussions among lawyers in a certain field or law students at a particular law school. ${ }^{78}$

Ms. JD is not just an isolated blog; it is a movement. There are approximately 1,100 registered authors on the website. ${ }^{79}$ The site averages 765 hits (or views) per day, and in the four weeks prior to August 8, 2008, it received over 21,400 hits. ${ }^{80}$ The homepage accounts for 533 of these daily hits (with about 15,000 homepage hits in the four weeks prior to August 8,2008 ). ${ }^{81}$ The blog was recently named one of ABA Journal's "Blawg 100" in the "Your So-Called Life" category. ${ }^{82}$

Ms. JD, which this Article uses as its representative blog or case study, is just one blog in a larger movement of blogs that focus on the legal profession, women's issues, and work-life balance more generally. Up to PAR (a blog started by the Project for Attorney Retention) "works to reduce attrition among

73. Ms. JD, Mission Statement, http://ms-jd.org/mission (last visited Sept. 17, 2008).

74. Id.

75. Telephone Interview with Elizabeth Pederson, supra note 67.

76. $I d$.

77. The forums are organized by discussion subjects, including "Advice \& Mentoring," "Public Interest, Government, Academia," "Making Partner," "Finding Time for Personal Life," "Study Techniques," "Financing Law School," "Taking the Bar," and "Job Hunt." Ms. JD Forums, http://msjd.org/forums (last visited Sept. 17, 2008).

78. See Ms. JD, Network, http://ms-jd.org/network (last visited Nov. 30, 2008).

79. E-mail from Ms. JD Bd. Member to author (Aug. 8, 2008, 10:54 EST) (on file with author). Registered users are people who have registered with Ms. JD to contribute original content, use the forums, or network, but do not include people who only read the blogs. Id.

80. Id.

81. Id. To put these numbers into context, the Huffington Post, one of the country's most well-read progressive blogs, received about eleven million hits per month. Telephone Interview with Editor, Huffington Post (Aug. 5, 2008). There are 2,500 registered bloggers. Id.

82. Ms. JD, The ABA Journal Blawg 100, http://ms-jd.org/aba-journal-blawg-100 (last visited Nov. $20,2008)$. 
lawyers... by promoting the use of reduced hour schedules and the advancement of women lawyers." 83 The blog features "[c]ommentary on news, alerts about trends, and discussion of personnel management practices" throughout the legal profession. ${ }^{84}$ The Project for Attorney Retention (PAR) website includes information for lawyers, law students, and law firms about non-stigmatized part-time programs, best practices for retaining lawyers, and a section called "The Scoop," which discusses how part-time really works at different firms. ${ }^{85}$ PAR's "Law Student Project," an online resources page dedicated specifically to the issues facing law students, is designed to show that "long-term career potential and a fulfilling life outside of the office shouldn't be mutually exclusive." $" 86$

Building a Better Legal Profession (BBLP) works to achieve "marketbased reforms in large private law firms." ${ }^{.87}$ Through its blog and its active presence on Facebook, ${ }^{88}$ BBLP

... publiciz[es] firms' self-reported data on billable hours, pro bono participation, and demographic diversity ... [and] encourage[s] those choosing between firms - students deciding who to work for after graduation, corporate clients deciding who to hire, and universities deciding who to allow on campus for interviews-to exercise their market power and engage only with the firms that demonstrate a genuine commitment to these issues. ${ }^{89}$

\section{B. The "Limited-Means" View of the Legal System}

One reason why women lawyers may blog is that they have considered the law as a means of rights assertion, but have rejected it as a "viable means for achieving change. ${ }^{, 90}$ This idea was articulated by Professor Crawford, who, in

83. Project for Attorney Retention, Up to PAR, http://lawyersworklife.blogspot.com/ (last visited Sept. 17, 2008).

84. Project for Attorney Retention, About Up to PAR, http://www.pardc.org/UpToPAR/ (last visited Nov. 20, 2008).

85. Project for Attomey Retention, http://www.pardc.org (last visited Nov. 30, 2008). The PAR website also includes a "Law Student Project" that provides law students with information they can use to research and identify legal employers that offer a challenging and rewarding workplace and also support a healthy work-life balance.

86. Project for Attomey Retention, Law Student Resources, http://www.pardc.org/LawStudent/ index.shtml (last visited Nov. 10, 2008).

87. Building a Better Legal Profession, http://www.betterlegalprofession.org/mission.php (last visited Sept. 17, 2008); see also Law Students Building a Better Legal Profession, http://refirmation. wordpress.com/ (last visited Sept. 17, 2008).

88. Facebook, launched in 2004 , is a "social networking website with over 100 million active users worldwide." See Facebook, Statistics, http:/www.new.facebook.com/press/info.php?statistics (last visited Jan. 20, 2008) (registration required).

89. Building a Better Legal Profession, supra note 87.

90. See Crawford, supra note 5, at 160 . The classic example of law's limitations with regard to gender equality is the refusal of the Supreme Court to elevate gender discrimination to the same level as racial discrimination. While racial discrimination receives a strict level of scrutiny in court, gender discrimination receives only an intermediate level of scrutiny. Under strict scrutiny the law in question 
asking why there is an "absence of meaningful consideration of the law" in young feminist writings, suggests that "[t]o young women in the twenty-first century, the law's limited ability to affect social change is obvious." noting that the "limited means" view of the legal system-the rejection of the formal legal system as a viable means of change described in this section-is slightly different from the "opting out" of the legal system described by Professors Ellickson, Bernstein, Richman, and Feldman. ${ }^{92}$ While Professor Ellickson and others describe how the law can be an overly blunt, intrusive, and impractical instrument of conflict resolution for many tight-knit communities, the women lawyers discussed in this Article do appear to appreciate the legal system in many respects. However, they understand that actual positive law does not necessarily favor their position or offer a fair solution to their problem. They recognize that, even in the many instances where there is a gender equity law on a particular issue, recent history has revealed significant limitations to the law's ability to serve as a tool for vindicating one's rights.

must be "necessary" to achieve a "compelling government purpose," while under intermediate scrutiny, the law need only be "substantially related" to an "important government purpose." See ERWIN Chemerinsky, Constitutional LaW: Principles and Policies 671 (3d ed. 2006). Presumably, intermediate scrutiny thus allows some laws to survive that would not otherwise survive under strict scrutiny, and these laws may discriminate against women. In Craig v. Boren, 429 U.S. 190 (1976), the Supreme Court used its discussion of the earlier case of Reed v. Reed, 404 U.S. 71 (1971), to articulate a standard of intermediate scrutiny for gender discrimination cases. As the National Women's Law Center describes it in their report, this standard required that laws which discriminate on the basis of sex "be justified under a 'heightened scrutiny'. . supported by an 'exceedingly persuasive justification' that is 'substantially related to an important government objective' and cannot be based on stereotypes about gender roles." NAT'L WOMEN'S LAW CTR., THE SUPREME COURT AND WOMEN'S RIGHTS: GATHERING STORM CLOUDS 5 (2006), available at http://www.nwlc.org/pdf/SCReport2006Web3.pdf (summarizing Reed v. Reed, 404 U.S. 71 (1971)). The Craig standard, while more rigorous than rational basis review, is less rigorous than the strict scrutiny standard applied to cases of discrimination based on ethnicity, national origin, or race-in these cases, the classification "must be narrowly tailored to further a compelling government interest." $I d$. at 6 . The court has struck down several laws that discriminate on the basis of gender under heightened scrutiny. See United States v. Virginia (VMI), 518 U.S. 515, 766 (1996) (exclusion of women from the state-owned Virginia Military Institute); J.E.B. v. Alabama, 511 U.S. 127, 107 (1994) (sex-based peremptory challenges). However, many commentators have criticized the intermediate standard of scrutiny, questioning why gender discrimination should not receive the same level of scrutiny as discrimination based on race. See Crawford, supra note 5, at 160. Further, in the past few years, there is evidence that even this intermediate level of scrutiny could be in jeopardy. In his $V M I$ dissent, Justice Scalia indicated that he would end heightened scrutiny for gender if given the chance to do so. VMI, 518 U.S. at 567-68. In Nguyen v. Immigration and Naturalization Service, 533 U.S. 53 (2001), Justice Kennedy wrote the majority opinion using the weaker version of heightened scrutiny that former Chief Justice Rehnquist articulated in his $V M I$ concurrence. In her strong dissent in Ngryen, Justice O'Connor warned of the risk the decision posed to the intermediate scrutiny standard previously applied to cases of gender discrimination: "No one should mistake the majority's analysis for a careful application of this Court's equal jurisprudence concerning sex-based classifications. Today's decision instead represents a deviation from a line of cases in which we have vigilantly applied heightened scrutiny to such classifications to determine whether a constitutional violation has occurred." Id. at 97 (O'Connor, J., dissenting). The National Women's Law Center has also warned women of a serious threat to the heightened scrutiny standard for gender discrimination: "If both Chief Justice Roberts and Justice Alito follow the former Chief Justice [who articulated a lower level of scrutiny in his concurring opinion to $V M I$, there may no longer be five votes for a vigilant and consistent application of the heightened scrutiny standard." NAT'L WOMEN'S LAW CTR., supra, at 7.

91. Crawford, supra note 5, at 160.

92. See supra notes $2-4$. 
Equal pay is one area where women lawyers are likely to reject the current law as a viable option for change. Instead, they employ blogging as a means of information-sharing and advice-gathering to make themselves stronger bargainers in the workplace. Despite the passage of the Equal Pay Act in $1963,{ }^{93}$ women who work full-time and year-round earn seventy-seven cents for every dollar earned by a man who works full-time, year-round. ${ }^{94}$ One of the main reasons for the persistent pay gap is the fact that "[w]omen are vastly overrepresented in traditionally female jobs with low pay, low status, and high turnover." Indeed, women hold $79 \%$ of jobs described as "administrative support occupations." 96 While these "administrative" jobs may require the same level of education and work experience as jobs occupied by men, women have no basis for an equal pay claim so long as the male-dominated jobs have a title different than "administrative."

Pay equity faced a major setback in 2007 when the Supreme Court rejected the EEOC's interpretation of Title VII in Ledbetter v. Goodyear Tire \& Rubber $\mathrm{Co}^{98}$ The EEOC had interpreted Title VII to allow claims of pay discrimination to be brought as long as the unequal pay continued. Plaintiff Lilly Ledbetter was one of the few female supervisors at a Goodyear tire plant and had worked there for two decades. Early in her career, she suspected that she was receiving fewer and lower pay raises than the male supervisors. However, Goodyear had a policy forbidding employees from discussing their pay. For years Ledbetter had no proof of the pay inequity, until one day she received an anonymous note revealing the salaries of three male supervisors. ${ }^{99}$ She filed a complaint the next day with the EEOC, her case went to trial, and the jury awarded her $\$ 3.3$

93. The Equal Pay Act, 29 U.S.C. $§ 206$ (d)(1) (2000) ("No employer having employees subject to any provisions of this section shall discriminate ... between employees on the basis of sex by paying wages to employees in such establishment at a rate less than the rate at which he pays wages to employees of the opposite sex in such establishment for equal work on jobs the performance of which requires equal skill, effort, and responsibility, and which are performed under similar working conditions, except where such payment is made pursuant to (i) a seniority system ....").

94. See Heidi hartmann, Olga Sorokina \& Erica Williams, InST. FOR Women's Policy RESEARCH, THE BEST AND WORST STATE ECONOMIES FOR WOMEN 1 (2006), available at http:// www.iwpr.org/pdf/R334_BWStateEconomies2006.pdf. Note that when the Equal Pay Act was passed in 1963 , women were making $60 \%$ of men's wages. By 1990 , the percentage had risen to $70 \%$. See VALENT1, supra note 66 , at 113 . Thus, given that the current percentage is $77 \%$, the number has only risen at a rate of $10 \%$ in the last 18 years.

95. LEVIT \& VERCHICK, supra note 18, at 73.

96. Id.

97. See, e.g., NAT'L COMm'N ON PAY Equity, Profile of THE Gender Wage GaP By Selected OCCUPATIONS FOR THE YEAR 2000, available at http://www.pay-equity.org/PDFs/occupation2000.pdf (showing that women comprise $77 \%$ of the "Admin. support, including clerical" job sector, where they are paid on average $\$ 500$ less per month than those working in "Securities and Financial Services Sales," where men comprise $66 \%$ of the job sector).

98. Ledbetter v. Goodyear Tire \& Rubber Co., 550 U.S. 618, 127 S. Ct. 2162 (2007). Because the U.S. Reports version of the case is still in slip copy at the time of writing, I refer to the second citation form for pincite page numbers.

99. See NAT'L WOMEN'S LAW CTR., LEDBETTER V. GOOdYEAR TIRE \& RUBber CO.: THE SUPREME COURT LIMITATION ON PAY DisCRIMINATION ClAimS AND THE LEGISLATIVE FIX 1 (2008), available at http://www.nwlc.org/pdf/Broad\%20Ledbetter\%20Fact\%20Sheet-Letterhead.pdf. 
million in compensatory and punitive damages for the extreme nature of the pay discrimination. ${ }^{100}$

In a 5-4 decision, the Supreme Court, while recognizing that Ledbetter had in fact been a victim of pay discrimination based on gender, nonetheless held that she could not challenge ongoing pay discrimination since Goodyear's original discriminatory pay decision occurred outside of the 180-day statute of limitations period. ${ }^{101}$ As a result of this decision, victims of pay discrimination who may not be aware of pay disparities when they are occurring (especially since many companies keep information about pay extremely private), or who are initially too afraid to file a complaint, are left without a remedy. ${ }^{102}$

Advocates have spent the past decade lobbying for "comparable worth" laws that would require women and men working in jobs of "comparable skill, effort, responsibility, and conditions" to receive comparable pay, ${ }^{103}$ and for other equal pay legislation that would expand the rights under the Equal Pay Act. These efforts have materialized into two important bills: the Fair Pay Act and the Paycheck Fairness Act. The Fair Pay Act was introduced by Senator Tom Harkin on April 11, 2007, and would "amend the Fair Labor Standards Act of 1938 to prohibit discrimination in the payment of wages on account of sex, race, or national origin." 104 More generally, it "seeks to end wage discrimination against those who work in female-dominated or minoritydominated jobs by establishing equal pay for equivalent work." " Ledbetter decision, the Bill was renamed "The Lilly Ledbetter Fair Pay Act," as its passage would in effect reverse the Supreme Court's ruling. ${ }^{106}$ Last year, the

100. Id. (discussing Ledbetter v. Goodyear Tire \& Rubber Co., No. 99-C-3137-E, 2003 WL 25507253 (N.D. Ala. Sept. 24, 2003)).

101. See Ledbetter, $127 \mathrm{~S}$. Ct. at 2165 . This interpretation reversed the longstanding EEOC "paycheck accrual rule," under which each new paycheck was treated as a separate discriminatory act that started a new 180-day clock. NAT'L WOMEN'S LAW CTR., supra note 99, at 2.

102. Justice Ginsburg, in her dissent, argued that because pay discrimination occurs in small increments over long periods of time, the 180-day limit should not apply. Ledbetter, $127 \mathrm{~S}$. Ct. at 2178 79 (Ginsburg, J., dissenting). Moreover, information about how others are paid is usually confidential and therefore unavailable for comparison. Finally, although many discriminatory actions are obvious, small discrepancies in pay are often difficult to see until more than 180 days of pay have passed. Id.

103. See Susan Gluck Mezey, in Pursuit of Equality: Women, Public Policy, and the FEDERAL COURTS 99 (1992) ("Comparable worth advocates contend that because job classifications with equal scores have equal value to the employer, they should claim the same wage--seniority and merit being equal. ... [The advocates] claim that sex segregation in the work force is one of the primary reasons for the salary gap between men and women. They argue that women are channeled into a small number of low-paying and low-prestige job categories").

104. Washingtonwatch.com, H.R. 2019, The Fair Pay Act of 2007, http://www.washingtonwatch. com/bills/show/110_HR_2019.html (last visited Sept. 17, 2008).

105. The Nat'l Comm. on Pay Equity, Current Legislation, http://www.pay-equity.org/info-leg.html (last visited Sept. 17, 2008).

106. Mike Hall, House Passes Bill to Close Pay Gap Between Women and Men, AFL-CiO NOW Blog, Aug. 1, 2008, http://blog.aflcio.org/2008/08/01/house-passes-bill-to-close-pay-gap-betweenwomen-and-men/. 
House passed the Lilly Ledbetter Fair Pay Act, but a Republican-led filibuster in the Senate blocked the bill from reaching the floor. ${ }^{107}$

The Paycheck Fairness Act was introduced on March 6, 2007 by Senator Hillary Clinton and Representative Rosa DeLauro to strengthen the Equal Pay Act of 1963. ${ }^{108}$ The bill "expands damages under the Equal Pay Act and amends its very broad fourth affirmative defense ... [and] calls for a study of data collected by the EEOC and proposes voluntary guidelines to show employers how to evaluate jobs with the goal of eliminating unfair disparities." 109 Just recently, the House passed the Act with a vote of 247 to 178. ${ }^{110}$

A recent National Association of Women Lawyers (NAWL) survey found that "male of counsels earn roughly $\$ 20,000$ more than females, male nonequity partners earn roughly $\$ 27,000$ more than females, and male equity partners earn almost $\$ 90,000$ more than female equity partners." 111 Thus, like women in countless other professions, pay discrimination persists for many women in the legal profession, and women are blogging about it. One commenter on Ms. JD discussed how Ledbetter has placed female lawyers who are paid less than men in an untenable position: They must either "put up (filing a lawsuit) or shut up (lose your right to equal pay) on a tightened timeline."112 The commenter pointed out the irony of the fact that she knows many female lawyers who may have been willing to engage in mediation and dispute resolution but now feel, post-Ledbetter, that they need to file suit immediately in order to recover. ${ }^{113}$ The blogger to whom the commenter responded wrote, "[T]his Supreme Court [is] far too quick to ignore discrimination against women or simply justify the inequities in the workplace. Frankly, it pisses me off!"114

In a different blog discussion, a blogger suggested that power dynamics in relationships might change when women, not men, were the higher wage earners. ${ }^{115}$ The blogger also began a discussion of Corporate Counsel's ranking

107. Id. Then Senator (now President-Elect) Barack Obama was among the co-sponsors of the Senate version of the bill. Id.

108. Nat'l Comm. on Pay Equity, supra note 105.

109. Id.

110. Am. Assoc. of Univ. Women (AAUW), AAUW Celebrates House Passage of Paycheck Fairness Act, http://www.aauw.org/About/newsroom/pressreleases/073108_paycheckFairness.cfm (last visited Nov. 10, 2008).

111. NAWL SURVEY, supra note 27; see also supra text accompanying notes 52-53. This survey takes into account the numbers of hours worked by each gender. Id.

112. Comment by Legal Eagle on Chicana, Supreme Court Builds Barrier to Equal Pay for Women, Ms. JD, May 29, 2007, http://ms-jd.org/supreme-court-builds-barrier-equal-pay-women.

113. Id.

114. Chicana, Supreme Court Builds Barrier to Equal Pay for Women, Ms. JD, May 29, 2007, http://ms-jd.org/supreme-court-builds-barrier-equal-pay-women.

115. Peg, Money=Power=Masculinity??, Ms. JD, Feb. 2, 2007, http://ms-jd.org/money-powermasculinity. 
of the 100 highest paid general counsels (GCs) in America. ${ }^{116}$ The blogger highlighted the fact that only fifteen women made the list of 100 , and only one woman made it into the top twenty-five. ${ }^{117}$

To mark this year's Equal Pay Day (April 18, 2008), a blogger explained that she has written on the motherhood wage gap: "the penalty working mothers pay when they have children that cannot be attributed to reduced time or commitment in the office."118 She shared how "[n]ational longitudinal studies by the U.S. Department of Labor have documented a statistically significant drop in the wage trajectories of women with children not experienced by fathers." 119 Finally, one blog discussion suggested strategies for avoiding crying at work. In the course of the discussion, a blogger named Peg asked another blogger, Anna, for advice about how to have a discussion with her boss about a pay raise-a conversation she considered "stressful." "20 Anna commented that "many women in law ... express[] discomfort and a reluctance to request a raise at work." Anna suggested that Peg "reframe[] a personal confrontation as a confrontation on behalf of someone else," namely Peg's children. Together, Anna and Peg did the math and discovered that "a small raise now would mean a lot more money accruing later in [Peg's] children's college funds." Anna explained that "moms are fierce for their kids" and thinking this way would motivate Peg to have this discussion. "Getting past ourselves and our own insecurities can get us past a lot of tears." "121

These blog discussions around equal pay reveal that while women lawyers continue to face grievances in the workplace that could technically be addressed through the legal system-unequal pay being a prime example-they are fully aware of the law's limited ability to provide recourse. ${ }^{122}$ By discussing

116. Peg, How do Women General Counsels Stack Up?, Ms. JD, Jan. 2, 2008, http://msjd.org/how-do-women-general-counsels-stack.

117. Id. Peg also noted that "women [on the list] took home only $68 \%$ of what the average GC at the top took home." Id.

118. Jessie, Equal Pay Day: Scholarship on Advocacy and Equity, Ms. JD, Apr. 16, 2008, http://ms-jd.org/equal-pay-day-student-scholarship-advocacy-and-equity.

119. $I d$.

120. Anna, How to Avoid Crying at Work [Part 2 of 3], Ms. JD, Feb. 9, 2008, http://ms-jd.org/howavoid-crying-work-part-2-3.

121. Id.

122. There are other examples where a woman lawyer blogs about a grievance for which a law on point has been drafted, but the blogger recognizes the law's limited efficaciousness. One such example is sexual harassment. In U.S. sexual harassment cases, plaintiffs can prevail by demonstrating that the workplace "is permeated with 'discriminatory intimidation, ridicule, and insult." Harris v. Forklift Systems, Inc., 510 U.S. 17, 21 (1993) (citing Meritor Sav. Bank FSB v. Vinson, 477 U.S. 57, 65 (1986)). "Requiring the plaintiff to prove that harassment is 'unwelcome' implies that sexualized behavior on the job is otherwise normal, or at least consented to ... and most courts require Plaintiffs to prove the negative - that the harassment is unwelcome-as part of their prima facie case." LEVIT \& VERCHICK, supra note 18, at 68. For many women lawyers, possible instances of sexual harassment occur after work hours, outside the actual four walls of the office, and most often within a workplace that is not "permeated with discriminatory intent." Id. For an example of a woman angered by her male colleagues' sexually harassing behavior (but not planning to take legal action), see Curious, After Hours Harassment, Ms. JD, Apr. 20, 2007, http://ms-jd.org/after-hours-harassment. 
topics like the Ledbetter case and the Corporate Counsel survey, these bloggers begin to understand the realities of unequal pay for women in their own profession. They recognize that a woman's claim is barred if she does not find out that she is being paid unequally during the 180-day period after she receives her first unequal paycheck. In a situation like Peg's, a woman has used the blog to solve an individual problem. In blog entries like the ones discussing the Ledbetter case, women have used the blog to solve widespread, collective challenges. In both cases, by blogging about what various firms pay men and women, and by using blogs to discuss various ways in which to approach salary discussions, women are using an alternative method to address grievances that are legal in character.

Discussions about equal pay provide just one example of blog discussions on Ms. JD that emanate from a recognition of the law's limited ability to effect change. Other such examples include:

When Should I Tell My Firm I'm Pregnant ${ }^{123}$-A blogger describes how she feels "uneasy" trying to broach the topic of being pregnant with her law firm and her partner mentor because "it's very hard to predict how someone (especially a woman) will react to this kind of news ... and I [am] worried that coming to her with a "personal" issue would be unwelcomed and lower my professional worth in her eyes." ${ }^{\text {,24 }}$ Another blogger brings up the laws that are in place: "You've been hired, you're [legally] entitled to the leave, and you should take it ... there's no reason to be ashamed, you also should tell them right away...." ${ }^{\prime 25}$ Several other bloggers join the discussion with various pieces of advice. Two weeks later, the original blogger came back online and thanked all those who gave her advice: "I went in and talked to the Recruiter at my firm yesterday, and it went fantastically! ... I am glad to know that so many people are making it work." 126

Judge Boon's Reprimand Also Demonstrates Progress ${ }^{127}$-This comment reports that "when news broke that Maryland Judge W. Kennedy Boone was reprimanded in January for calling three AfricanAmerican women lawyers 'the Supremes' and advising the defendant to 'get an experienced male attorney," the incident led the American Bar Association to revise its Model Code of Judicial Conduct and

123. Slh245, When Should I Tell My Firm I'm Pregnant, Ms. JD, Apr. 22, 2008, http://msjd.org/when-should-i-tell-my-firm-i039m-pregnant.

124. Comment by Manamana on Slh245, When Should I Tell My Firm I'm Pregnant, Ms. JD, Apr. 22, 2008, http://ms-jd.org/when-should-i-tell-my-firm-i039m-pregnant.

125. Comment by Anonymous on Slh245, When Should I Tell My Firm I'm Pregnant, Ms. JD, Apr. 22, 2008, http://ms-jd.org/when-should-i-tell-my-firm-i039m-pregnant (second comment, entitled "I Also Think You Should Tell Them").

126. Comment by Slh245 on Slh245, When Should I Tell My Firm I'm Pregnant, Ms. JD, Apr. 22, 2008, http://ms-jd.org/when-should-i-tell-my-firm-i039m-pregnant.

127. Comment by Lynn Hecht Schafran on Jessie, Sexism, Sexual Harassment, and Other Forms of Discrimination, Ms. JD, Feb. 22, 2008, http://ms-jd.org/topic/issues/sexism-sexual-harassment-andother-forms-discrimination. 
adopt "a new Canon that directed judges not to manifest bias or prejudice on a list of grounds including sex, and not to permit those under their direction and control to do so."128

A well-known blogger described how blogging has become "a powerful tool for those looking to change laws that may not be working." 129 Indeed, for a blogger like Peg, blogging and getting advice from Anna about how to be paid better will likely prove to be a catalyst for change. ${ }^{130}$

\section{Institutional Mindset: The "Maternal Wall" and the "All-or-Nothing" Workplace}

Women lawyers may also blog when there is a need to transform the mindset or implicit bias of an employer, rather than the employer's behavior. When discussing the possible reasons why women lawyers are drawn to Ms. JD, Pederson explains Ms. JD's shrewd recognition that "[t]he battle has changed" for women lawyers: While it "used to be about actual behavior, now [it's] about mindset."131

The conversation about improving the representation of women in the profession used to be focused on actual, identifiable behaviors but now the obstacles women face are amorphous. The blog allows women lawyers to strategize about what we can do to make the profession a place where more women lawyers are able to succeed. ${ }^{132}$

Deborah Epstein Henry, one of the nation's foremost experts on women in the legal profession, believes that the biggest hurdle for women lawyers is that "there has always been a male-defined model for success."

[W] hen women want to work alternatively, they are made to feel as if they are not committed, not talented and won't succeed. We have rigid notions of part-time and full-time that are fallacies and are leading us down the road to a work-life crisis. Blogging allows women to discuss these issues and draw attention to them.

Similarly, a female partner at a top New York law firm discusses the need for law firms to "recognize that... to retain talented women, and increasingly

128. Id.

129. E-mail from Arianna Huffington, supra note 1.

130. It is important to acknowledge that while women can use blogging to induce positive changes in their workplace lives, it is unfortunate that the laws as currently drafted cannot be more responsive to the obstacles that plague these women. Some might argue that blogging about issues like equal pay may actually detract from the need to reform a certain positive law. This is an important concern to raise but beyond the scope of this Article.

131. Telephone Interview with Elizabeth Pederson, supra note 67.

132. Id.

133. Telephone Interview with Deborah Epstein Henry, Founder, Flextime Lawyers LLC (Dec. 5, 2007).

134. Id. 
men, [they] must provide flexibility while at the same time, acknowledg[e] that these people can still practice law at the highest levels of excellence."135

The male mindsets and "male models" that Pederson and Henry allude to manifest themselves in two discrete phenomena-the "maternal wall" and the "all-or-nothing" workplace. ${ }^{136}$ The "maternal wall," a phrase coined by Joan Williams, is the idea that "many women are pushed out of good jobs and into economic vulnerability, when they hit the 'maternal wall'-the equivalent for mothers of the glass ceiling that all women face." ${ }^{\text {"137 }}$ Williams describes two "related phenomena" that together make the maternal wall "a particularly high one for women to scale in the United States" workplaces: "bias against workers with family responsibilities" and "workplace inflexibility." "138 Williams quotes a working mother's perception of her own workplace: "Anyone who cuts back [on work] is not a team player, and is not considered for [quality]... assignments .... In most companies, you're taken off the fast track and you miss out on plum assignments." 139

Williams has also coined the term "all-or-nothing," which describes the "idea that 'full-time' in professional and managerial jobs has spiraled up towards 50 or more hours a week." 140 Discussions of part-time versus full-time work and the dichotomy's effect on women have long been a focus of feminist scholarship:

In today's workplace, most part-time workers are at a serious disadvantage to full-timers; they usually receive no pro-rata fringe benefits, many types of jobs are closed to them, and they may even be paid at a base rate lower than full-time workers doing the same job. The great majority of part-time workers are also women.... The standard of 40 hours [for the American work week], it seems, is not a magic number but reflects the average amount of time that men work. The standard for everyone is thus premised on the norm of only part of the working population... under the standard, men's experience is privileged. ${ }^{1}$

Alongside the "all-or-nothing" workplace is the increased speed of the legal profession. One female partner discusses the "increased pace" that "grinds all

135. Telephone Interview with partner at a major New York law firm (Nov. 30, 2007).

136. See generally WILlIAMS, MANVELl \& BORNSTEIN, supra note 48 (discussing phenomena of "maternal wall" and "all or nothing workplace").

137. Id. at 29 .

138. Id.

139. Id. at 30 (alteration in original).

140. Id. at 24 .

141. Chamallas, supra note 17, at 7. Part-time work is also undervalued economically: "At least in part as a consequence of poor remuneration, American workers are comparatively unlikely to work part-time; women workers in all of our study countries [including the United States], Finland excepted, report higher rates of part-time work." JANET C. GORNICK \& MARCIA K. MEYERS, FAMILIES THAT WORK: POLICIES FOR RECONCILING PARENTHOOD AND EMPLOYMENT 171 (2003). In addition, individuals who work forty-four hours per week on average earn twice as much as those working thirtyfour hours per week. See Warren Farrell, Exploiting the Gender Gap, N.Y. TIMES, Sept. 5, 2005, at A21. 
people in the profession, whether you work full-time or reduced hours, and makes it harder to separate what you do inside and outside the office." ${ }^{\prime 142}$ She adds that with all of the new technology, "we are expected to work 24-7, and it is assumed that everything can be done instantly. If you don't do it instantly (even if a client does not need it instantly) you are not as valued by the law firm."143

Many women are blogging in an attempt to change both the "maternal wall" and the "all-or-nothing" workplace. A recent blog entry on Ms. JD" ${ }^{144}$ discussed Women Lawyers and Obstacles to Leadership, a report issued by the Women's Bar Association, Massachusetts Bar Association, and the Boston Bar Association. ${ }^{145}$ The report's main finding is that institutional mindset remains the largest obstacle to women's success in the legal profession: "The loss of women to leadership in the law follows directly from a failure in the profession to respond imaginatively to a dual need for time-time for work and time for families." ${ }^{146}$ The report concludes:

[B]uilding time for families into law firm practice is not a general institutional norm. The availability of flexible arrangements for family care is indeterminate, unpredictable. Finding a way to combine law firm practice and care for families is at present an individual responsibility, and it generally carries professional penalties[.] Change in these practices is essential if women are to advance to leadership in the legal profession. ${ }^{147}$

Another blogger wrote about an advice column by Ann Israel, a wellknown New York legal recruiter, which appeared in the New York Law Journal. ${ }^{148}$ A female associate who had recently started a job at a top New York law firm and wanted to have a child during her second year at the firm asked Ms. Israel whether "taking maternity leave so early on [would] derail my career permanently?"149 She also asked, "Will the firm view me as unserious?"150 The female associate was planning to return to the firm full-

142. Telephone Interview with partner at major Washington, D.C. law firm (Oct. 30, 2007).

143. Id.

144. Judge Nancy Gertner, The Revolution of Falling Expectations, Ms. JD, Oct. 3, 2007, http://ms-jd.org/revolution-falling-expectations; see also Lawblogger, Demanding a More Livable Profession: Why Women Lawyers Who Want It All Aren't the Problem, Ms. JD, June 5, 2007, http://msjd.org/demanding-more-livable-profession-why-women-who-want-it-all-arent-problem.

145. See Mona Harrington \& Helen HSi, Women LaWyers and Obstacles to Leadership: A REPORT OF MIT WORKPLACE CENTER SURVEYS ON COMPARATIVE CAREER DECISIONS AND ATTRITION RATES OF WOMEN AND MEN IN MASSACHUSETTS LAW FIRMS (2007), available at http://web.mit.edu/workplacecenter/docs/law-report_4-07.pdf.

146. Id. at 38 .

147. Id. at 34 .

148. Anna, Legal Recruiter Answers the Question: Will Taking Maternity Leave in My First Few Years As an Associate Derail My Career?, Ms. JD, Feb. 7, 2008, http://ms-jd.org/will-taking-maternityleave-my-first-few-years-associate-derail-my-career (discussing Ann Israel, Advice for the Lawlorn, N.Y. L.J., Feb. 6, 2008).

149. Israel, supra note 148.

150. $I d$. 
time, and thus, was only asking about taking the standard, two-to-three months of maternity leave offered to all female employees at her firm. Ms. Israel responded to the associate,

[I]f you suspect that your firm's partners will believe you are not serious about your career because you take a maternity leave during your second year with the firm, and your career is the most important thing in your life, then perhaps you need to rethink whether or not you want to have children at this time.... In other words, you need to rethink your priorities and what you want. ${ }^{151}$

The blogger was distressed that Israel's "unspoken answer" to the question of "will taking maternity leave derail my career permanently?" was essentially a yes. ${ }^{152}$ The blogger then described how writers like Ann Israel are "disingenuous" in advising women that "if we just work hard enough beforehand, "hopefully ... we will be sorely missed' by senior partners."

Another blogger discussed how some of her co-workers describe women working part-time as "lazy working mothers," and others assert that "every" woman secretly wants to be a full-time mother."153 "The enemy here," the blogger wrote, "is not working mothers, who are painted as cheeky women who mistakenly think they can have it all. The enemy is a profession that requires any of its participants to live their jobs and only their jobs." ${ }^{\text {"154 }}$ She urged women to engage men in the effort to shift the business models of law firms so that this no longer continues to appear as only a working mothers issue, but rather as an obstacle for "both men and women." ${ }^{\text {"55 }}$ Similarly, another blogger discussed how characterizing work-life balance as a women's issue or even as a parents' issue is highly problematic:

Characterizing [work-life balance] as a women's issue does nothing more than reinforce the outmoded ideas that women care less about their careers than men and that men are less interested in family life than women. Characterizing it as a parent's issue cheapens the value of the childless person's home and social lives, as though the out-of-work commitments of the person without children are worth less simply because they don't involve offspring. ${ }^{156}$

One Ms. JD blogger describes how the "maternal wall" combined with the "all-or-nothing workplace" particularly affects women lawyers:

It would seem this [law firm] model has never heard of efficiency. I would argue that parents (and more often mothers are the primary carers in practice still) have time management skills that allow them to

151. Id.

152. Anna, supra note 148.

153. Lawblogger, supra note 144.

154. Id.

155. Id.

156. Wallflower, The Work-Life Balance Sales Pitch, Ms. JD, Feb. 2, 2007, http://ms-jd.org/worklife-balance-sales-pitch. 
be much more efficient even [if] they require them to be out of the office more to care for children. This model puts no value at all on that.... I really think the worst kind of sexism is in the business model itself. And grateful as I am to those women in the 1970s who expanded our opportunities in law by sacrificing their own families and work-life balance, they did us no favours by just conforming to the male-gendered business model. ${ }^{157}$

Obstacles like the maternal wall could theoretically be addressed through the legal system, specifically through lawsuits challenging family responsibility discrimination (FRD). Joan Williams describes FRD lawsuits on her website:

Pregnant women, mothers and fathers of young children, and employees with aging parents or sick spouses/partners may find themselves discriminated against. They may be rejected for employment, demoted, harassed, passed over for promotion, or terminated-despite good performance evaluations-simply because their employers make personnel decisions based on stereotypical notions of how they will or should act. ${ }^{158}$

Federal anti-discrimination laws such as Title VII of the Civil Rights Act of $1964,{ }^{159}$ as well as federal family leave laws such as the Family and Medical Leave Act, ${ }^{160}$ make family responsibility discrimination illegal. ${ }^{161}$ The Center for WorkLife Law has tracked over 800 FRD cases filed through $2006 .{ }^{162}$ Ninety-three percent of the cases involved female plaintiffs. ${ }^{163}$ FRD plaintiffs are statistically more likely to prevail when compared to other employment discrimination plaintiffs, and personal liability awards are often significant: The mean award for damages was $\$ 785,976$ and the median was just over $\$ 100,000 .{ }^{164}$ However, despite the fact that FRD suits are a viable option, many women lawyers choose instead to blog about these same issues.

157. Comment by Veronica on Sintecho, Does Sexism Still Exist?, Ms. JD, Mar. 13, 2008, http://ms-jd.org/does-sexism-still-exist.

158. Work Life Law, Family Responsibilities Discrimination, http://www.worklifelaw.org (last visited Nov. 10, 2008).

159. See 42 U.S.C. $\S 2000 \mathrm{e}-2$ (a) (2000) ("It shall be an unlawful employment practice for an employer-(1) to fail or refuse to hire or to discharge any individual, or otherwise to discriminate against any individual with respect to his compensation, terms, conditions, or privileges of employment, because of such individual's race, color, religion, sex, or national origin ....").

160. See 29 U.S.C. § 2612(a)(1) (2000):

... [e]ligible employee shall be entitled to a total of 12 workweeks of leave during any 12-month period for one or more of the following: (A) Because of the birth of a son or daughter of the employee and in order to care for such son or daughter. (B) Because of the placement of a son or daughter with the employee for adoption or foster care. (C) In order to care for the spouse, or a son, daughter, or parent, of the employee, if such spouse, son, daughter, or parent has a serious health condition. (D) Because of a serious health condition that makes the employee unable to perform the functions of the position of such employee.

161. See Work Life Law, supra note 158.

162. WILLIAMS, MANVELL \& BORNSTEIN, supra note 48 , at 46.

163. Id.

164. Id. 
In one recent entry titled Bias Against Children, the blogger, a single mother working at a boutique law firm, discussed how a partner had emailed her the night before with a task that needed to be done, but the blogger had already left work to pick up her child from daycare "on the other side of town." ${ }^{165}$ The next morning, the blogger touched base with the partner about the assignment. The partner informed her that the assignment had been completed by someone else, adding that "some of us have to work." 166 The blogger, disheartened by this exchange, reasons that if she is receiving comments like these at her small firm, she will have to "give up [her] dreams of having one of the wine \& dine [big law firm] jobs . ..."167 Another blogger working at a larger law firm suggested that she might think about the situation differently:

It is a shame to hear that your 'dream' is to work at a big firm and that you are not going to pursue that dream.... [A] big organization may be just what you need-one that has the resources to have things like flex-time, job share and other accommodating policies that may mean there are real options for attorneys that aren't looking to bill crazy hours. ${ }^{168}$

This exchange demonstrates the power of the blog as a vehicle to talk through some of the same issues implicated in family responsibility discrimination.

One very active blogger started blogging on Ms. JD because she was "having a tough time as a mother working in a law firm."169 "I was worried that any sort of reduced hours would take me off partnership track and that is actually a goal of mine. . . I am open about wanting to be a partner." ${ }^{170}$ This woman had looked at the policy manual for her firm when she was choosing places to work. ${ }^{171}$ The manual described a "'well-established"" part-time policy for both associates and partners. ${ }^{172}$ "“Don't even think about doing it," was the advice she received from all the associates on her hallway. After starting to work part-time, the blogger realized her colleagues were correct. With reduced hours, she was dropped from much of her current work, and no longer received the best assignments. ${ }^{173}$ To remedy her situation, she started visiting Ms. JD.

Whether it is through comparing information about how other firms are doing it [dealing with alternative schedules] and bringing that information to my own firm, or getting advice about how to have a difficult conversation with my firm's leadership about what has

165. Bangalee57, Bias Against Children, Ms. JD, Jul. 16, 2008, http://ms-jd.org/child-bias.

166. Id.

167. Id.

168. Comment by KHeman881 on Bangalee57, Bias Against Children, Ms. JD, Jul. 28, 2008, http://ms-jd.org/child-bias.

169. Telephone Interview with Ms. JD blogger 2 (Dec. 10, 2007).

170. Id.

171. Id.

172. Id.

173. Id. 
happened to me since I started working part-time, the blog [Ms. JD] has allowed me to begin to convince people at my firm that the choice to work part-time does not mean that I, and women generally, are any less committed to professional success and to a career at the firm. ${ }^{174}$

\section{The Grievance Is Nonlegal in Character}

In addition to airing discriminatory grievances like unequal pay (which has a legal remedy, albeit limited by current law), and institutional grievances like the maternal wall (which could be addressed legally, though the real challenge is shifting mindset, not behavior), women lawyers may blog when their grievances are neither legal nor the product of institutional bias. Instead, these women's grievances emanate from societal and cultural biases that lie outside the purview of the workplace.

An example of such a grievance can be found in blog discussions about gender dynamics inside the household. The division of labor inside a typical American household is far from equal. "Mothers still spend nearly twice as long as fathers doing core household tasks ... [and] nearly twice as much time as fathers caring for children...."175 Men's household contributions often have a direct bearing on women's success in the workplace. As Williams explains, "Because most men do not carry an equal share of household work, women's ability to accept promotions or to remain in good jobs is constrained." 176 Just as women suffer from the lack of male contributions to

174. Id.

175. WILliAMS, MANVELL \& BORNSTEIN, supra note 48, at 20.

176. Id. at 21. Interestingly, the phenomenon of unequal division of labor in the household also undermines the effectiveness of certain laws, and in turn relates to the first reason why women may blog. See supra Part II.B (discussing the limitations of certain laws that women lawyers might otherwise turn to for relief). One such example is the Family and Medical Leave Act of 1993 (FMLA), which requires employers with fifty or more employees within a seventy-five-mile area to grant any employee "up to twelve weeks of unpaid leave during a twelve-month period for the birth and care of a newborn, the arrival of an adopted or foster child, or the care of a family member, or for an employee's own serious medical needs." LEVIT \& VERCHICK, supra note 18, at 63; see 29 U.S.C. $§ \S 2611,2612$ (2000). The FMLA has many weaknesses that prevent it from accomplishing full equality for women in the workplace, the most obvious being that the leave is unpaid. The lack of paid sick leave disproportionately affects women in the workplace because unequal gender roles in the household mean that, in heterosexual families, women, rather than their male partners, are the ones who take sick leave to care for their children. Eighty percent of mothers have primary responsibility within their families for selecting their children's doctors, accompanying children to appointments, and following through with care. See VICKY LOVELl, INST. FOR WOMEN'S POL'Y RESEARCH, WOMEN AND PAID SICK DAYS: CRUCIAL FOR FAMILY WELL-BEING 2 (2007), available at http:/www.iwpr.org/pdf/B254_ paidsickdaysFS.pdf. As a result, half of working mothers report missing work when their child is sick while only $30 \%$ of working fathers report missing work in the same circumstances. Henry J. Kaiser Fam. Found., Women, Work and Family Health: A Balancing Act, ISSUE BRIEF, Apr. 2003, at 2, available at http://www.kff.org/womenshealth/loader.cfm?url=/commonspot/security/getfile.cfm\& PageID=14293. Another study found that "being female doubles the chance of experiencing job loss because of family illness." See NAT'L PARTNERSHIP FOR WOMEN AND FAMILIES, PAID SICK DAYS ARE GOOD FOR WOMEN 2, available at http://www.nationalpartnership.org/site/DocServer/WorkingWomen. pdf?docID=121 (citing Seymour Spilerman \& Harris Schrank, Reponses to the Intrusion of Family Responses in the Workplace, 10 RES. IN SOC. STRATIFICATION \& MOBILITY 27, 61 (1991)). In contrast, 
household labor, many men in the workplace benefit from the disproportionately large female contributions to household labor.

Many professional men with children have wives who don't work outside the home, at least if there are young children in the picture; meanwhile, very few working women, mothers or otherwise, have husbands who don't work outside the home. ${ }^{177}$

Occurring alongside the "all-or-nothing" workplace, the idea of an "all-ornothing" mother has developed. "Women are caught between new, more time consuming versions of what it means to be a good mother and a good worker." 178 One law firm partner believes that women's persistent role as the primary homemaker remains women lawyers' greatest hurdle:

I think the main issue for women in law firms is that they have babies and men do not and the prime years of child-rearing coincide with the traditional time in which law firm lawyers are logging long hours, showing their stuff, and growing professionally. The concurrence of those two things, combined with the fact that women still are expected to assume, and do assume, most of the child-rearing responsibilities, is the reason we have seen attrition of women from law firms. ${ }^{179}$

She also describes how this year alone, "two female associates told [her] that they had to quit when their husband's job was transferred," despite the fact that "[t]hese women made between $60 \%$ and $70 \%$ of their household income, could have been on partner track, and enjoyed their work." 180

In a blog discussion forum titled, "Is Being a Mother and a Lawyer a LoseLose Situation?", a blogger on Ms. JD asked,

$[\mathrm{H}] \mathrm{ow}$ will I cope with the guilt of leaving my kids behind even for a short time? And what about the guilt to co-workers who have to pick up the slack? And even if I can get past those two things, will I ever be satisfied with not being able to give 100 percent to my career and my kids?

I guess my question is for those who are currently working mothers-is it a lose-lose situation? ${ }^{181}$

only $13.5 \%$ of male workers requested leave under the FMLA, and of those, $57.6 \%$ took leave for personal reasons. U.S. DEP'T. OF LABOR, WAGE \& HOUR DIVISION, THE 2000 SURVEY REPORT, tbls. A2-2.6 \& A2-2.27 (2000), available at $\mathrm{http} / / / \mathrm{www} . d o l . g o v / \mathrm{es} / \mathrm{whd} / \mathrm{fmla} / \mathrm{APPX}-\mathrm{A}-2-\mathrm{TABLES} . \mathrm{htm}$.

177. Rosa Brooks, What the Internet Age Means for Female Scholars, 116 YALE L.J. POCKET PART 46, 47 (2006), http://www.thepocketpart.org/2006/09/20/brooks.html. One writer describes the "contemporary model in which anxious moms spending their days in the care [sic] driving overscheduled kids to a steady stream of 'enrichment' activities, and work themselves into a frenzy to 'be there' for their children." WILLIAMS, MANVELL \& BORNSTEIN, supra note 48, at 27 (discussing JUDITH WARNER, PERFECT MADNESS: MOTHERHOOD IN THE AGE OF ANXIETY (2005)).

178. WILLIAMS, MANVELL \& BORNSTEIN, supra note 48, at 25.

179. Telephone Interview with partner, supra note 135.

180. Id.

181. Eralon, Is Being a Mother and a Lawyer a Lose-Lose Situation?, Ms. JD, Aug. 14, 2007, http://ms-jd.org/being-mother-and-lawyer-lose-lose-situation. 
She received several thought-provoking responses which offered concrete advice as well as a wide range of perspectives on her question. Those who felt it was not a lose-lose situation said:

Since becoming a mother, I have definitely had to sacrifice, but I have tried to limit my sacrifices to those I can live with: I don't watch t.v., I haven't a clue what the hot restaurant in town is anymore, and my childless friends are fewer now. ... Work hard to be a superstar before you have kids (i.e., prove your value), and then take advantage of your firm's part time policy. Since having kids, I have had to become more efficient, and learn to delegate more and take on less.... It helps to have a really reliable nanny/housekeeper. It helps if there are other mothers at your firm that you can lean on, learn from and vent to. ${ }^{182}$

Recruit your husband, extended family and caregivers for blocks of weekend time so that you can work and then return to your family for a focused period with them. ${ }^{183}$

One of those who felt it was a lose-lose situation said:

I grew up in the 70s and $80 \mathrm{~s}$ and formed the opinion that I could have it all if I worked hard enough and made the right decisions ... [but] [t] here have been too many situations to list or count that I have been disappointed in myself as a mother. For example last year I missed my son's five year birthday party because I had to work, unexpectedly. ... My advice, before you decide to be a mother and an attorney, come to the realization that you can't be everything to everyone. Understand that you will make compromises and sacrifices. If you are a person like

I was, compromises in the area of personal success is a foreign concept. Today, it is part of my daily life. ${ }^{184}$

Perhaps most insightfully, one blogger emphasized what had gone unsaid and was absent from this discussion: "For what it's worth-no one has ever told my husband he is not giving $100 \%$ as a parent because he works more than full time as a doctor." ${ }^{185}$ As this blog discussion demonstrates, grievances stemming from gender dynamics inside the household, while related to the "allor-nothing" workplace and the "maternal wall" phenomenon, do not lend themselves to legal recourse, and have less to do with how a workplace is treating its employees and more to do with societal and cultural ideas about gender dynamics inside a family.

Some bloggers describe these domestic or inside-the-household gender obstacles as presenting women with an even greater challenge than any

182. Comment by sneubert on Eralon, Is Being a Mother and a Lawyer a Lose-Lose Situation?, Ms. JD, Aug. 14, 2007, http://ms-jd.org/being-mother-and-lawyer-lose-lose-situation.

183. Comment by ptlawmom on Eralon, Is Being a Mother and a Lawyer a Lose-Lose Situation?, Ms. JD, Aug. 14, 2007, http://ms-jd.org/being-mother-and-lawyer-lose-lose-situation.

184. Comment by KHeman881 on Eralon, Is Being a Mother and a Lawyer a Lose-Lose Situation?, Ms. JD, Aug. 14, 2007, http://ms-jd.org/being-mother-and-lawyer-lose-lose-situation.

185. Comment by TND on Eralon, Is Being a Mother and a Lawyer a Lose-Lose Situation?, Ms. JD, Aug. 14, 2007, http://ms-jd.org/being-mother-and-lawyer-lose-lose-situation. 
particular workplace policy. For example, Pederson notes that while many law firms have adopted progressive policies, the industry "remains client-driven and service-oriented [and thus] firms cannot move away from the billable hour model even if their intention is to do so." ${ }^{\text {186 }}$ Moving towards a model "where success is not necessarily about the time and exact hours you put into your work but about the quality of your performance," explains Pederson, "is important because no matter how much we progress in the workplace, the reality is that inside the home, women continue to have more responsibility than men. [Thus], measuring success only by hours will therefore disadvantage women." 187

In addition to issues of domestic feminism, many blog postings on Ms. JD discuss societal and cultural issues like the dearth of female mentors, the lack of networking opportunities for women, general strategies for advancement in the profession, and whether or not to act in a feminine manner. These are all challenges that cannot be addressed through a legal system, but that instead involve transforming cultural and societal ideas about women. Examples of such blog discussions include:

Finding a Good Mentor Requires Strategy-Discussing an American Bar Association publication that outlines various ways to be a "proactive mentee" in the legal profession because "mentorship is not something that you chance to happen upon but rather something that you actively seek out based on how they can 'help you shape your career." $" 188$

\section{Truths Every Working Woman Should Know Before Having a} Child-"1) Pregnancy is Bliss and Shouldn't Impact Your Ability to Work; 2) Lamaze Classes are Required Training; 3) Post-partum Depression is Only for the Weak-minded; 4) Stay At Home Dad is the Perfect Solution to My Work-life Balance Concerns; 5) Breastfeeding is Easy and Natural; 6) Grandparents Will Come to the Rescue; 7) You'll be the Same Person But Now You'll Just Have a Kid."189

One blogger says that she began blogging to develop a network of women lawyers. "I was ready for an old girls club and this online network has allowed me to connect with mentors, potential sources of clients, and other women who provide me with strategies about how to navigate the workplace." ${ }^{, 190}$ Another

186. Interview with Elizabeth Pederson, supra note 15.

187. Id.

188. Sintecho, Finding a Good Mentor Requires Strategy, Ms. JD, Nov. 24, 2007, http://msjd.org/finding-good-mentor-requires-strategy (reviewing ANN FARMER, AM. BAR ASSOC., BEND AN EAR, STRENGHTHEN YOUR PATH: THE PROACTIVE MENTEe (2006)).

189. Peg, 7 Truths that Every Working Woman Should Know Before Having a Child-Part I, Ms. JD, Nov. 30, 200, http://ms-jd.org/7-truths-every-working-woman-should-know-having-child-part-i (Part I in a series of seven; this part gives an overview of the entire series).

190. Telephone Interview with Ms. JD blogger 1 (Nov. 1, 2007). 
blogger was "thirsty to connect to other women," especially "mentors," when she started blogging on Ms. JD. ${ }^{191}$

There are only a few women partners in my law firm, all the women associates go to them, and frankly, some do not act like mentors. So, I wanted to find new women who have more experience than me, and would be able to give me advice about law firm life as a woman and as a mother. ${ }^{192}$

Blogging about domestic, cultural, and societal issues (as opposed to more institutional and legal issues) reveals that the challenges facing working women span the public-private divide, and that blogging is being employed as a methodology to address working women's grievances both inside and outside the workplace. As one blogger explains,

Society has to recognize that women have been tasked with many things outside the workplace, including raising the children and taking care of a household, and they have done as much as . . . humanly possible to make a 24-hour day work. In that way, there is an argument to be made that issues facing women lawyers are more about society and workplaces having to accommodate families and domestic gender issues, and less about firms having to change specific policies. More generally, firms are recognizing that women are just as smart and productive as men but are still burdened by outside responsibilities. This is something most women have known all along. ${ }^{193}$

Blogging, Pederson argues, "transform[s] private grievance[s] into professional ones." "194 "When [Ms. JD] bloggers write on the site, they are blogging about their private and personal thoughts and women throughout their professional community can interact with these private thoughts." 195

\section{E. Blogging Because It's Easier}

Women lawyers may blog about their grievances simply because blogging is a low-cost, highly accessible, and relatively safe way to advocate for their rights in the workplace-and because it is a technology that was not available to them in years past. Ms. JD founder Elizabeth Pederson says she started blogging because it was "easy and informal."196 "Blogging is cheap and easy. It requires no travel because you can blog whenever and wherever you want. And, it feels accessible. You can do it alone at your desk, choose an alias and write about what's on your mind." ${ }^{197}$ Some bloggers are attracted to the

191. Telephone Interview with Ms. JD blogger 2, supra note 169 .

192. Id.

193. Telephone Interview with anonymous blog founding member 3 (Aug. 29, 2008).

194. Id.

195. Id.

196. Id.

197. Telephone Interview with Elizabeth Pederson, supra note 67. 
anonymity of the medium, particularly the ability to be anonymous and yet feel incredibly empowered:

[A] lot of women like myself are afraid to say what they think and don't want to make waves. Lots of women have arguably been harassed and they don't want to do anything that will hurt them professionally or lead to retaliation. But blogging allows them to start a conversation, and get connected to other women so they know they are not the only ones who have gone through something, and so they have ideas about how to approach the challenge. ${ }^{198}$

Interestingly, despite these enthusiastic endorsements of anonymity, an informal survey of Ms. JD suggests that many bloggers do not, in fact, choose to blog anonymously. For example, a screen capture taken of the Ms. JD homepage on August 4, 2008 reveals nine new discussion threads. ${ }^{199}$ Of those nine, only one poster used a pseudonym or alias. Two posters used their personal e-mail addresses, six used their names and four of those six included a photograph of themselves with their name.

In addition to anonymity and convenience, bloggers like Arianna Huffington are attracted to the speed of blogging:

I like[] the immediacy of the medium, the ability to connect with an audience directly, intimately, and rapidly... [B]logging and the Internet allow one to quickly research and understand the issues at hand, and to connect with others who might have useful information. ${ }^{200}$

\section{F. Critiques of Blogging}

Blogging is not without its critics, and many are particularly critical of the anonymity associated with blogging. These critics are concerned that anonymity may detract from the honesty and potentially lasting influence of a blog discussion. "The one problem I see with blogs," Flextime Lawyers founder Debbie Epstein Henry explained, "is that most often, complete honesty cannot come with anonymity."201 Only one blogger who was interviewed for this Article actually blogs with her real name. She explains, "I believe in

198. Telephone Interview with anonymous blog founding member 2 (Dec. 9, 2007).

199. It is important to note that this screen snapshot captures only new blog entries, and does not include any comments responding to blog entries written before August 4, 2008.

200. E-mail from Arianna Huffington to author, supra note 1.

201. Telephone Interview with Deborah Epstein Henry, supra note 133. Concerns about anonymity are certainly compelling. Critics like Epstein Henry are perhaps reasonable in doubting the candor and investment of a woman who will not "stand by" her beliefs by signing a name. In fact, when I set out to write this Article, my hope was to cite to my interviews with bloggers by their names and include some biographical information about them. Without exception, the bloggers I interviewed preferred to remain anonymous in my piece, with one blogger changing her mind shortly before publication because someone in her workplace had leamed that she liked to blog. While this may simply be a result of the fact that, by speaking with me, they fear that they reveal even more than they do through the blogging itself, I feel it is worth noting. 
everything I have written, and I think it will mean more to people reading it to see that I have included my name. I fear that other women lawyers may read the blog and say, "well, of course she can raise these issues because she is not using [her] own name.",202

This same blogger, however, questions whether blogging will actually shield women from retaliation and harassment. "Women continue [to be] just as vulnerable online as they are offline." ${ }^{, 03}$ Jill Filipovic, a feminist blogger and NYU law student, has written extensively about her own experience being harassed on AutoAdmit, ${ }^{204}$ a blog where "anonymous posters leave hundreds of comments every day about law school admissions, top schools, and law firms-along with sexualized and sexually aggressive comments about female law students." ${ }^{, 205}$ Male law students who were angered by Filipovic's feminist blog postings (some of which can be found on Ms. JD) reacted by blogging on Auto Admit about "raping" and "hate-fucking" Filipovic, and debating whether she was "fuckable" or a "fat bitch." 206 Of the experience, Filipovic writes,

The anonymous online attacks on female bloggers and law students follow a similar narrative [to offline ones]. When women write about politics or technology or ... a traditionally male field like law, they are reminded of their secondary status through sexualized insults, rape threats, and beauty contests. ... They remind her that even if she is a top law student at a top law school, her primary purpose is decorative.... ${ }^{207}$

Some critics, particularly academics, fear that blogging will simply "replicate many of the hierarchical and gendered structures found in the offline world of legal scholarship." 208 Rosa Brooks, a feminist law professor, has written about "the promises and perils that the Internet holds for women in the legal academy." 209 Brooks first posits that "[i]n the [legal] academy, where one's work is never done at 5:00 pm, those with fewer family and household responsibilities [that is, men] have more time for scholarship... [and] visibility." 210 She suggests that while the Internet has the potential to "eliminate

202. Telephone Interview with Ms. JD blogger 1, supra note 190.

203. Id.

204. AutoAdmit, http://www.xoxohth.com/ (last visited Sept. 17, 2008).

205. See Jill Filipovic, Blogging While Female: How Internet Misogyny Parallels "Real-World" Harassment, 19 YALE J.L. \& FEMINISM 295, 295 (2007). The sexualized insults she and other women bloggers have faced on the Internet "reflect attempts to put women in their place, just as rape threats attempt to keep women fearful in an effort to relegate them to the domestic sphere." Id. at 302 .

206. Jill Filipovic, When Law Students Attack, Ms. JD, Mar. 7, 2007, http://ms-jd.org/node/174.

207. Filipovic, supra note 205 , at 303 . In discussing "beauty contests," Filipovic is referring to AutoAdmit's "The 'Most Appealing' Women @ Top Law Schools," a site where bloggers posted and discussed photographs of a dozen women from top law schools, many of them (including Filipovic) in their bikinis. Id. at 296. The page has since been taken down.

208. Brooks, supra note 177 , at 50. Professor Brooks asks whether the "Internet-driven transformation of legal scholarship [is] good for the girls, or bad for the girls." Id. at 46 .

209. Id. at 46 .

210. Id. at $47-48$. 
some of the barriers faced by women legal scholars,"211 "the online world of legal scholarship may ultimately replicate many of the hierarchical and gendered structures found in the offline world."212

The concern about blogs replicating a gendered hierarchical structure seems to have been a motivating factor behind making Ms. JD, outwardly and openly, a blog for women: "A secondary goal of forming Ms. JD," explained Pederson, "[w]as to provide a safe space for women where they could express their opinions freely and openly and comfortably."213 It is not clear that this goal would be reached if Ms. JD were a blog about the legal profession generally and attracted male bloggers. Arianna Huffington, however, feels strongly that her blog, and blogging more generally, has leveled the playing field: "[Blogging] allows young women the chance to express themselves without having to clear the many hurdles that are traditionally placed in the way of anyone looking to reach the public-but, especially women, and especially, especially young women." 214

Finally, one might argue that due to the ease of blogging, women's involvement in women's issues might be more tenuous and superficial because women are blogging about challenges rather than addressing them in a more "active" way. In other words, because blogging is quick and easy, women might think they have done their "feminist work" by posting an entry on a blog. To Pederson, this concern appears to be ill-founded.

Whatever motivates Ms. JD bloggers to blog on the site, they are not blogging in lieu of attending a meeting of a women's organization or lobbying their representative. In fact, it's quite the opposite. Most of the bloggers I know are thinking, discussing and writing about the challenges facing women because of their involvement in blogging. Blogging allows the writer to process thoughts and opinions about these experiences more fully than they otherwise might. Many times, women have not formulated their thoughts on these issues until they blog. 215

\section{Blogging As Feminist Legal Method}

Feminist legal theory, with its "explicit reliance on feminism as the guiding force behind its inquiry into law," is the "[c]riticism of the law from a feminist

211. Id. at 50. The Internet allows for shorter articles, one can blog or post articles on SSRN at anytime of day from anywhere, and blogs have helped many female scholars become noticed. Id.

212. Id. Brooks has two central concerns. First, because blogging is $24 / 7$ and attracts "the obsessive, the energetic, and the insomniac," for the same reasons as offline legal scholarship, "women are likely to be left behind." Id. at 50-51. Second, she worries that the anonymity of blogging-a different setting from the "civilized realm of the conference halls and the faculty lounge"-will allow for "no-holds-barred speech" that can be "nasty, often in gendered ways." Id. at 51.

213. Interview with Elizabeth Pederson, supra note 15.

214. E-mail from Arianna Huffington, supra note 1.

215. Interview with Elizabeth Pederson, supra note 15. 
standpoint." 216 Feminist legal theorists have developed a series of different directions, moves, and methodologies that feminist critiques may follow.

Feminism is ... the range of committed inquiry and activity dedicated first, to describing women's subordination-exploring its nature and extent; dedicated second, to asking both how-through what mechanisms, and why-for what complex and interwoven reasonswomen continue to occupy that position; and dedicated third, to change. $^{217}$

Martha Chamallas, a prominent feminist legal scholar, has developed a list of "recurring moves" that feminist scholars have used to "place women at the center rather than the margins of the study of the law." 218 In some sense, blogging is a modernized version of many of these methods. In other ways, blogging embodies its own methodological commitments.

Blogging has allowed women to examine and criticize the legal profession from a feminist standpoint. It has done so by increasing the scope of consciousness raising, expanding the diversity of viewpoints, transcending dilemmas of difference, and honestly confronting women's choices or lack thereof. In each of these ways, blogging is redefining the ways in which women address contemporary women's issues and thus represents a new feminist legal method.

\section{A. Women's Experience and Consciousness Raising}

The women's movement has historically placed great emphasis on the importance of women's experience. This emphasis "can be traced to the consciousness-raising (CR) groups of the late 1960s and early 1970s, where women were encouraged to express their subjective responses to everyday life and discovered that their personal problems also had a political dimension." 219 Through CR, "women begin to view what otherwise might appear as isolated instances of insensitivity or chauvinism as symptoms of broader societal oppression." 220 For much of the 1970s and 1980s, CR was accomplished in meetings at feminist organization headquarters, book clubs, knitting circles ("stitch and bitch" sessions), and intimate gatherings in people's homes. ${ }^{221}$ However, as increasing numbers of women have entered the "all or nothing" workforce, urban sprawl has pushed women farther away from one another, and the activist community has become less about membership in a particular organization and more about working on issues at one's own convenience,

216. ChAMALlas, supra note 17 , at $1,2$.

217. Clare Dalton, Where We Stand: Observations on the Situation of Feminist Legal Thought, 3 BERKELEY WOMEN'S L.J. 1, 2 (1987) (emphasis added).

218. ChamalLAS, supra note 17 , at 4.

219. Id.

220. LEVIT \& VERCHICK, supra note 18 , at 49.

221. Id. at 50 . 
these traditional CR groups have become impracticable. "Membership in national women's organizations continues to drop. Women who might have been inclined to attend traditional CR groups are working full-time, raising a family, and with the little time they have, may not want to spend the evening at NOW [The National Organization for Women] headquarters."222 Blogging, Valenti explains, "is the modern form of consciousness raising." 223 Whether or not its founder realized it at the time, Ms. JD was clearly started as a vehicle for consciousness raising:

While there is no longer a clear "glass ceiling," in our everyday lives as women lawyers and law students, we know that we are up against something. Women are still not achieving success at the same rate as their male counterparts. We started Ms. JD to find a solution to this disparity and to hypothesize about what that ceiling might be. The blog is a way of talking about the things that need to be said and sharing the stories that need to be shared. ${ }^{224}$

Another blogger says she started blogging to gain a heightened awareness and understanding about the ways in which her gender might affect her career. "It all started when I was sworn into the California bar," she recalls. "I was walking into the building where the swearing in was to occur with my male colleague, and an old classmate of his stopped to ask him if I was his wife. I was so angry that I went back to the office and blogged about it."225

Chamallas describes the CR of the 1960s and 1970s: "[W]omen were encouraged to express their subjective responses to everyday life and discovered that their personal problems had a political dimension."226 Indeed, as women blog on Ms. JD about subjects like the "maternal wall" and the "allor-nothing" workplace, women are "expressing their subjective responses to everyday life," and the CR described by Chamallas is occurring. In fact, there is an argument to be made that $\mathrm{CR}$ occurring over blogs actually far exceeds the scope of the CR that was possible in years past. For example, Chamallas discusses in her scholarship how the term "sexual harassment" did not exist until the mid-1970s, despite the fact that sex discrimination in employment was outlawed as early as $1964 .{ }^{227}$ She explains that, for many years, "harassing

222. Telephone Interview with Jessica Valenti, Founder, Feministing.com (Dec. 10, 2007). Feminist activists Jennifer Baumgardner and Amy Richards describe today's women activists' frustration with "meeting fatigue" (referring to women's lack of time to attend multiple long meetings) and suggest that activism is no longer about "a willingness to pay $\$ 20$ and add [your] name to an e-mail petition but about actually working on issues that matter to you." JENNIFER BAUMGARDNER \& AMY RICHARDS, GRASSROOTS 58, 60 (2005)

223. Telephone Interview with Jessica Valenti, supra note 222.

224. Telephone Interview with anonymous blog founding member 1 (Dec. 9, 2007).

225. Telephone Interview with Ms. JD blogger 2, supra note 169.

226. Chamallas, supra note 17 , at 4.

227. Id. at 5. Chamallas cites to the influential feminist scholar, Catharine MacKinnon, when describing the development of the term "sexual harassment." In her landmark book on the subject of sexual harassment, MacKinnon recollects how "the term 'sexual harassment' was first used in 1975 by a women's advocacy organization in connection with the case of Carmita Wood . . . an administrative 
conduct tended to be dismissed as harmless flirtation. A transformation in the cultural meaning of such conduct [only] occurred when women workers began to express their negative responses" about it to one another. ${ }^{228}$ Thus, the nearly two-decade lapse between the outlawing of sex discrimination in the workplace and the time "sexual harassment" became a recognized term is likely due to the fact that women could not express to one another their negative responses to harassment, because women did not have the means through which to connect with, and communicate to one another. Today, blogs like Ms. JD come closer to ensuring that even when women are separated by distance and workplace settings, they can connect through the Internet. If there were a pattern of sexual harassment at law firms, it's fairly clear that women would use Ms. JD for CR, "nam[ing] their grievances and reinterpret[ing] reality in a critical fashion."

It is important that I address a potential critique of my argument that blogging exceeds the scope of past forms of CR. One might argue that because women are not meeting one another face-to-face, but only through the Internet, there is less of a networked feeling, and, in that sense blogging is actually less of a CR experience. In recent months, however, the act of blogging has formed such intense and deep connections among bloggers that virtual $\mathrm{CR}$ has translated into in-person CR, much like that of the $1960 \mathrm{~s}, 70 \mathrm{~s}$, and $80 \mathrm{~s}$. For example, Ms. JD has just launched a National Women Law Students Organization (NWLSO) which had an in-person inaugural meeting (a leadership summit) the weekend of April 4, 2008 in New York City. ${ }^{230}$ The NWLSO was founded by the most active bloggers on Ms. JD, most of whom did not know one another until they started blogging. ${ }^{231}$ They launched NWLSO with the recognition that "currently there is no national organization that represents women law students across the country, despite recent reports that women are now less likely than men to apply to law school and continuing statistics that women are less likely than men to reach the highest echelons of the legal profession." 232 There were over 100 delegates in attendance at the April 4 meeting, representing over fifty different law schools across the country. ${ }^{233}$ Some might argue that the conference is proof that people seek a more human connection than that offered by blogging. I would suggest instead that the conference demonstrates the intensity of the CR occurring on blogs like

assistant at Comell University who finally quit her job after being subjected to a pattern of offensive sexual behavior by her supervisor." Id.; see also CATHARINE MACKINNON, SEXUAL HARASSMENT OF WORKING WOMEN: A CASE OF SEX DISCRIMINATION 42 (1979).

228. Id. at 6.

229. Id. at 5 .

230. Ms. JD, Ms. JD National Women Law Students Leadership Summit, http://ms-jd.org/summit (last visited Sept. 17, 2008).

231. Telephone Interview with Elizabeth Pederson, supra note 67.

232. Ms. JD, supra note 230.

233. For a list of participating law schools, see Ms. JD, Participating Schools, http://msjd.org/participating-schools (last visited Sept. 17, 2008). Each law school was allowed to send two delegates. 
Ms. JD, such that perfect strangers feel connected enough by expressions of personal experience to travel and meet one another in person.

A feminist scholar, Patricia Cain, has written of CR that understanding women's life experiences and articulating gendered exclusions in the law can only come from "listening carefully to the stories of female experience that come from others." ${ }^{234}$ While access to CR has traditionally been limited by geography (whether you lived close enough to attend a meeting), and by who you knew (whether you were a member of NOW or a feminist book club), today, any woman with a computer can blog on Ms. JD, share her own experiences, and "listen closely" to the stories of others. In a sense, then, blogging is "consciousness raising plus."

\section{B. An Ideological Commitment to Diversity of Voices and Viewpoints}

Blogging embodies a deep ideological commitment to a diversity of voices and viewpoints. Some bloggers would say that this is a departure from the feminist methodology of the past and thus represents a new methodological commitment. For example, critical race feminists argue that "in feminist legal theory, as in the dominant culture, it is mostly white, straight, and socioeconomically privileged people who claim to speak for all of us."235 Bridget Crawford, in describing ideological and methodological commitments of Third Wave feminists, writes that "third wave feminists decry the lack of diversity in the second wave of feminism. If first- and second-wave feminism sought an accretion of rights and power to women as a group, Third Wave feminism seeks recognition for the individual."236

Blogging has certainly expanded the diversity of viewpoints contributing to debate on women's issues. Valenti, the founder of Feministing.com, is inspired by the numbers of women bloggers who came to Feministing.com because they felt alienated from traditional women's organizations. "Blogging has allowed anyone to put their voice out there," explains Valenti. "Before, if you weren't in a woman's organization-which have been traditionally white and uppermiddle class--your voice couldn't be heard on feminist matters. Now, it doesn't matter who you are. You can put your voice out there."237

In a recent blog entry on Ms. JD titled "Licenciada: A Latina's Perspective on Entering the Legal Community," an anonymous blogger chronicles her story of working in the legal profession as a Latina woman. ${ }^{238}$ While working as a

234. Patricia A. Cain, Feminist Legal Scholarship, 77 Iowa L. REV. 19, 20 (1991).

235. Angela P. Harris, Race and Essentialism in Feminist Legal Theory, 42 STAN. L. REV. 581, 588 (1990).

236. Crawford, supra note 5, at 117-18.

237. Telephone Interview with Jessica Valenti, supra note 222.

238. Anonymous, Licenciada: A Latina's Perspective on Entering the Legal Community, Ms. JD, Oct. 16, 2007, http://ms-jd.org/licenciada-latinas-perspective-entering-legal-community. 
legal secretary at a law firm, the blogger was admitted to law school. She shared her good news with a white male law student who was working as a summer associate at the law firm. The summer associate responded to her, "Oh, yeah, well you're a minority and female, so of course they'd take you. ${ }^{, 239}$ In addition to sharing this anecdote, the blogger described her later experience in law school: She was one of only four Latinas in a class of nearly two hundred and there were no Latino faculty at her law school. ${ }^{240}$ In response, another blogger empathized with the Latina blogger and asked whether comments like those of the male summer associate could be considered discrimination:

I think it becomes difficult when this type of man is a partner or associate who only gives assignments to the other white male associates. So then this sort of discrimination is nuanced and difficult to prove. Often the people at the bottom of the assignment line are the minority women. That is when you fight the battle ... when it affects the work you do and the opportunities you have earned. Thanks for raising this issue as these feelings apply to many women. Women who are minorities within the female population in a law firm often feel isolated and alone, but dialogue like this can help build a larger community of support among all women fighting to gain acceptance and respect in the legal community. ${ }^{241}$

Pederson similarly suggests that one of the greatest accomplishments of Ms. JD is its diversity of viewpoints. Unlike some women's organizations, "we stay clear from any political agenda, and encourage diverse political viewpoints. Our blog is about a single issue-women in the legal professionand that is certainly one that transcends politics and political parties."242

Blogging also helps to ensure that women engaging in $\mathrm{CR}$ are not just communicating to one another, or preaching to the choir, but are speaking to a larger audience than that to which they traditionally have access. As Arianna Huffington explains, "Blogging has done a lot to level the media playing field. The largely male poobahs who control the traditional media outlets are no longer the exclusive guardians of the gateways to the public."243 Valenti admits that the audience for many women bloggers is still smaller than traditional media outlets. ${ }^{244}$ Perhaps, then, there is an argument to be made that by blogging, women are accepting a less powerful medium of communication. Huffington, however, maintains that compared to years past, "[b]logging gives

239. Id.

240. Id.

241. Comment by Chicana on Anonymous, Licenciada: A Latina's Perspective on Entering the Legal Community, Ms. JD, Oct. 16, 2007, http://ms-jd.org/licenciada-latinas-perspective-entering-legalcommunity.

242. Interview with Elizabeth Pederson, supra note 15.

243. E-mail from Arianna Huffington, supra note 1.

244. Telephone Interview with Jessica Valenti, supra note 222. 
access-and potential power-to anyone with a laptop and a strong take on things." 245

\section{Double Binds and Dilemmas of Difference}

Another branch of feminist methodology grapples with the double bind in which women in the workplace find themselves-do they act like the men in their office, or do they embrace the more feminine qualities that they may have? Chamallas writes, "In contrast to the popular media, which often depict women as having already attained equality with men, feminist scholarship is far more skeptical about what passes for progress."246 Chamallas discusses the famous case of Price Waterhouse v. Hopkins, ${ }^{247}$ the "classic example of a double bind". 248

Hopkins was an ambitious female manager in a large accounting firm who consistently outperformed men on a number of conventional standards .... She nevertheless was denied a partnership in the firm because the male partners objected to her lack of social graces and her unfeminine style. For their taste, she was too aggressive, abrasive and macho. The double bind for Hopkins arose because even if she had been able to soften and feminize her appearance and style, she might still have not made partner. The problem is that in male-dominated settings such as elite accounting firms, feminine women are often regarded as lacking the competitiveness, technical competence, and ambition to make the grade. Either course of action was precarious for Hopkins because there is no predetermined script for success for women in such contexts. ${ }^{249}$

While blogging may not provide a complete "predetermined script," it certainly has started to draft one, and thus informed the feminist methodology of exploring the "dilemmas of difference." "s50 Spirited debates over how "feminine" one should act in the workplace occupy a large part of discussions on Ms. JD and provide a variety of viewpoints to those who visit the site. In The New Professional Dress: Ladies, Leave Your Feminine Dress at Home, one blogger argues that "the top female professionals often maintain their queen of the mountain status only by ruling like a king," and suggests that wearing pantsuits is one way to do so. ${ }^{251}$ She continues, "[f]or women in the workplace, 'feminine' behavior is more associated with secretaries than with partners, and to differentiate themselves and project 'professionalism,' women are often forced to embrace the masculine paradigm of

245. E-mail from Arianna Huffington, supra note 1.

246. CHAMALLAS, supra note 17 , at 8.

247. 490 U.S. 228 (1989).

248. Chamallas, supra note 17 , at 9.

249. Id. (emphasis added).

250. Id. at 8-10.

251. Anonymous, The New Professional Dress: Ladies, Leave Your Feminine Charms at Home, Ms. JD, Feb. 1, 2007, http://ms-jd.org/new-professional-dress-ladies-leave-your-feminine-charms-home. 
behavior to be taken seriously." ${ }^{252}$ However, within the discussion, the blogger recognizes that the

balance is a delicate tightrope walk indeed since women who go too far in emulating traditionally masculine characteristics are criticized for their lack of femininity. . . . Smile too much (they'll call it ingratiating) or laugh too often (they'll say you giggle), and you're soft and unable to be taken seriously. Maybe you're naive or sweet or just too reminiscent of so-and-so's granddaughter to be viewed as professionally competent. ${ }^{253}$

Other such discussions on Ms. JD include:

Is There Such a Thing as Professional Anger for Women?--discussing the pros and cons of showing emotion as a female lawyer in a professional setting. ${ }^{254}$

Developing a "Persuasive Presence"-discussing how women lawyers can avoid minimizing themselves with soft voices, undermining openers, and diminishing endings when they speak publicly. ${ }^{255}$

How to Avoid Crying at Work (Part 1 of 3) - offering twelve tips as to how women can avoid crying at work, including focusing on breath, ignoring the urge to cry, or deflecting with a white lie. ${ }^{256}$

Some scholars argue that discussions like these have allowed women to finally embrace the idea that any choice they make is a feminist one, and that they do not have to appear like men to succeed if they do not choose to.

In order to conquer the workplace as women, we need to approach it in our own unique way, not as carbon copies of men - [not as] briefcasecarrying, pinstripe-wearing career machines who just happen to [be women]... women have specific work-related fears that center on ambitiousness and assertiveness. The way to overcome these fears is by learning [through blogs] how to go beyond the men's office "game" but tailoring it to our own style. Blogging is a terrific way to share that knowledge and transcend it. ${ }^{257}$

Others argue that a deliberate and intentional focus on "women as different from men in the workplace" only sets women back, and that notions of difference should not be exaggerated or embraced by blogging or any other discussion forum on women's issues:

There is nothing more annoying than having firms bring up their parttime programs to you during an interview without you asking,

252. Id.

253. Id.

254. Sintecho, Is There Such a Thing as Professional Anger for Women?, Ms. JD, Jan. 11, 2008, $\mathrm{http}: / / \mathrm{ms}$-jd.org/there-such-thing-professional-anger-women.

255. Elizabeth, Developing a "Persuasive Presence," Ms. JD, Jan. 7, 2008, http://ms-jd.org/ developing-quotpersuasive-presencequot.

256. Anna, How to Avoid Crying at Work [Part 1 of 3], Ms. JD, Feb. 16, 2008, http://msjd.org/how-avoid-crying-work-part-1-3.

257. E-mail from Arianna Huffington, supra note 1. 
especially when you know that they are not speaking to male candidates about the program. It makes you feel like you're considered on a different path from the beginning. ${ }^{258}$

While blogs like Ms. JD have certainly allowed women to explore methods of grappling with these dilemmas of difference, it would be disingenuous to claim that blogging has solved the dilemma. As long as the leadership of any professional sector remains as heavily male-dominated as that of the legal profession, the dilemma will persist, because it "stems from the fact that most large institutions follow practices and policies saturated with implicit male bias." ${ }^{259}$ As Chamallas describes:

Simply to follow these "neutral" rules and ignore gender reproduces patterns of exclusion and paradoxically assures that gender will continue to matter in the world. However, to pursue a different strategy and implement an "affirmative action" program that focuses explicitly on gender also may backfire. The danger of taking gender into account is that it will stigmatize the group as different and inferior, and thereby reinforce gender differences. This "dilemma of difference" means that neither ignoring nor highlighting gender will necessarily translate into progress for women. ${ }^{260}$

While feminist activists may be disheartened that these sorts of conversations and dilemmas continue to persist - the The New Professional Dress: Ladies, Leave Your Feminine Dress at Home discussion on Ms. JD frighteningly resembles the 1980 s discussions of whether women should or should not wear shoulder pads to appear more like men-they should at the same time be encouraged by the fact that that women now have a space to hold these conversations (blogging) and are able to enter the workplace with advice from hundreds of women about what choices about masculinity versus femininity did and did not work for them. Blogging has created a forum where women can converse openly about dilemmas of difference. And whether difference is embraced or rejected by the participating bloggers, blogging helps ensure that the dilemma is explored fully enough so as never to be equated with inferiority.

\section{Activism from the Ground Up}

"Third Wave feminists are dissatisfied with earlier feminists and the movement they have created;"261 they see the movement as "top-down," because national women's organizations dictate to women what issues are important to them instead of allowing women to determine the agenda for

258. Telephone Interview with Ms. JD blogger 1, supra note 190.

259. Chamallas, supra note 17 , at 10.

260. Id.

261. Crawford, supra note 5 , at 116 . 
themselves. ${ }^{262}$ Describing a national women's organization, feminist activists Baumgardner and Richards write, "If there is one drawback to the proliferation of Feminist Majority campus groups, it is that their top-down structureactivist priorities are provided from the home office-isn't flexible enough to allow local campus issues, which might be more timely and inspiring, to dominate the agenda." 263 A related concern is the elitism of the women's movement. One college student describes how, at her college, "there was this feeling that if you weren't already well versed in feminist history and culture, then you just couldn't be a part of feminism.,"264

Blogging has allowed women to define the issues that they care about and want to work on. Blogging has also allowed women to work on women's issues without necessarily realizing that they are engaging in feminist activism, and thus it is a feminist method that engages many women who are not selfidentified feminists. One of the most active bloggers on Ms. JD does not identify as a feminist. ${ }^{265}$ Yet, when asked whether the issues she faces at her law firm have anything to do with gender, she answered, "I guess some of the issues do come from discrimination against women, but a lot more come from the inflexibility of the workplace or societal and cultural ideas about women in the workplace and as mothers." 266 Jessica Valenti feels that blogging has helped increase the numbers of women working on women's issues:

The feminist movement has in years past, been cliquish, [sic] in DC and New York. Now, anyone can be engaged, and can choose their level of engagement. They don't need to hold a protest sign. Instead, they can just read a blog, comment on it, write a blog entry, or even start their own blog like I did. Blogging allows any woman who wants to, to air their personal and professional grievances. ${ }^{267}$

There is, of course, the concern that blogs may also come to revolve around specific leaders or a core group of bloggers. It bears noting that the founders of Ms. JD came from the Boalt Hall, Cornell, Georgetown, Harvard, New York University, Stanford, UCLA, University of Texas at Austin, University of Chicago, University of Michigan, University of Virginia, and Yale law schools. ${ }^{268}$ These are all Top 25 law schools. ${ }^{269}$ This could lead some to fear that the feminist legal blogosphere is, or will come to be, dominated by top law schools and law firms. While the identity of the female legal bloggers is unavailable at the present time (and is impossible to gather unless the blogs

262. BAUMGARDNER \& RICHARDS, supra note 222, at 60 .

263. Id.

264. Id. at 59.

265. Telephone Interview with Ms. JD blogger 2, supra note 169 ("I am not a feminist").

266. Id.

267. Telephone Interview with Jessica Valenti, supra note 222.

268. Ms. JD, About Us, http://ms-jd.org/about (last visited Sept. 17, 2008).

269. See U.S. News \& World Report, Best Law Schools (Ranked in 2008), http://gradschools.usnews.rankingsandreviews.com/grad/law/search/ (last visited Sept. 17, 2008). 
themselves conduct surveys of their membership), the bloggers I interviewed for the piece came from a diverse group of law schools and backgrounds. While this is by no means a scientific sample, it suggests that the membership of Ms. JD has expanded beyond the law schools involved in its founding.

At present diversity means the diversity of viewpoints and experiences. By drawing from women's subjective experiences and engaging in cultural critique, rather than becoming involved in solving problems that happen to be on the radar of national women's organizations, younger women bloggers are working on "ground up" change-working on the issues that they talk about, read about, and care about-rather than "top down" change-focus on the laws and women's issues they are told to care about. As a result, women are addressing many questions that may have lain dormant in years past.

\section{E. Unpacking Women's Choices}

Chamallas discusses how "women's inequality presents a paradox.,"270 "Many who would endorse gender equality as an ideal," she explains, "nevertheless resist the idea that discrimination is the principal cause of women's inequality. Instead, women's subordinate status is often ascribed to women's own choices, and women are held responsible or blamed for their own disadvantages." ${ }^{271}$ Like Chamallas's discussion, a significant portion of feminist scholarship is "devoted to unpacking the concept of 'choice' and investigating the constraints under which women commonly make choices." 272 For example, Vicki Schultz, another well-known feminist scholar, unpacks the idea of women's choices by challenging and ultimately refuting the idea that women "choose" not to work in blue-collar jobs: ${ }^{273}$

[T]his cultural coding of jobs is reinforced by the persistent and often virulent harassment of women who try to break though gender barriers. Absent some affirmative indication by employers that women are welcome and will be supported in non-traditional work ... it is likely that the percentage of women in such jobs will remain extremely low, that women will "choose" not to enter this line of work or will quit once they realize what they face. ${ }^{274}$

In other words, Schultz's account of the low numbers of women in bluecollar jobs does not focus on women's choices, desires, and motivations in isolation, but instead focuses on these choices in the setting and against the backdrop of women's unique experiences. "This shift in emphasis complicated

270. Chamallas, supra note 17, at 11.

271. Id.

272. Id. at 12.

273. See Vicki Schultz, Telling Stories About Women and Work: Judicial Interpretations of Sex Segregation in the Workplace in Title VII Cases Raising the Lack of Interest Argument, 103 HARV. L. REV. 1749 (1990).

274. ChAMALLAS, supra note 17, at 12 (describing Schultz, supra note 273). 
the notion of choice, making it a function of present opportunities and contexts as well as preexisting preferences.",275

Like Schultz's inquiry into women's "choices" with regard to blue-collar jobs, discussions on Ms. JD often center around unpacking women's choices. For example, as discussed in Part II of this Article, there has been a spirited backlash across the blogosphere against the idea of an "opt-out" revolution. Women lawyers are using blogs to assert that they are not "opting out" of law practice, but instead being "pushed out" as a result of the "maternal wall," the "all-or-nothing" workplace, and persistent gender inequality inside the household. ${ }^{276}$ Others, however, argue that women lawyers are, in fact, opting out. One female partner laments how only three women she knows from her Top 10 law school are working. "While there may be forces pushing women out of the workplace, it would be dishonest not to admit that many women are choosing not to work.",277

Whichever view one takes, it's evident that, through blogging, these women lawyers are engaging in a contemporary incarnation of Chamallas's traditional feminist methodology of "unpacking choice." Like Schultz, they are using blogging to shift the emphasis. Rather than focusing simply on what women are "choosing" to do or not to do, they are looking critically at forces external to the individual woman such as employer behavior, corporate polices, domestic divisions of labor, and limitations in the law. Chamallas describes these forces as "distinctive constraints placed on women in a male-dominated society." ${ }^{278}$ By "unpacking choices" over the blogosphere, women are working towards transforming implicit male bias and shifting the mindset of the profession in the hope that women will only leave the workforce when they truly make the choice to do so. ${ }^{279}$

\section{F. Blogging as a New Feminist Legal Method}

Blogging about women's issues on Ms. JD is, in essence, a means of criticizing the law as it is lived in the everyday lives of women lawyers in the workplace; it is a form of criticism that comes "from a feminist standpoint." 280 Specifically, blogs like Ms. JD have allowed women to examine and be critical of the legal profession from such a feminist standpoint. All of the aforementioned blog entries on Ms. JD explore and describe women's

275. Id. at 13 .

276. For a detailed discussion about the "opt out" assumption and the backlash against it, see supra Part I.B. For a detailed discussion of the "maternal wall" and the "all-or-nothing workplace," see supra Part II.C. For a detailed discussion of domestic gender inequality, see supra Part II.D.

277. Telephone Interview with female partner from New York law firm (Aug. 7, 2008).

278. ChamalLas, supra note 17 , at 13.

279. For a discussion of the significant impact that blogs have had on the profession, see infra Part IV.

280. Chammallas, supra note 17 , at 2 . 
experiences, and ask "both how ... and why . . women continue to occupy"281 the positions they currently hold in the legal profession. Blogs have fostered this exploration by increasing the scope of consciousness raising, expanding the diversity of viewpoints, transcending dilemmas of difference, and honestly confronting women's choices or lack thereof. In all of these ways, blogging is redefining the methods through which women address contemporary women's issues, and thus it represents a new feminist legal method.

\section{The IMPACt OF BlogGING ON THE LEGAL Profession}

The founders of Ms. JD were a dozen female law students who plainly understood that comprising nearly half of all law school graduates-and by extension, half of the pool from which law firms would be recruiting-women law students possess a tremendous power in numbers. This is the power to create change by drawing attention to and comparing the practices of legal employers, as well as by calling for policy changes and institutional shifts in the legal workplace. "While our goal was certainly not to demonize workplaces .... we did want to recognize employers who are excelling at addressing these issues [and to] share the experiences of women who have been successful in changing their workplaces," explains Pederson. ${ }^{282}$ "We also wanted to make the information women might need to make an informed decision about where they want to work more widely available."283

Blogs like Ms. JD ${ }^{284}$ and Building a Better Legal Profession ${ }^{285}$ appear to have succeeded in leveraging market pressures to change business practices. Legal recruiting directors across the country have seen an increase in the numbers of men and women - both law students and lateral hires-who ask about work/life issues during the interview process. A legal recruiting director at a top New York law firm describes the impact the Internet has had on her department:

With websites like American Lawyer and Vault, as well as blogs like Above the Law and Ms. JD, and with independent groups doing research and presenting numbers over the Internet, the Internet and blogging has certainly impacted the view that firms have taken with regard to women's issues. Law students ask about work/life issues more than they ever have before because [they have] the information to compare workplaces. We have someone in our department for whom

281. Dalton, supra note 217 , at 2.

282. Telephone Interview with Elizabeth Pederson, Founder, Ms. JD (Dec. 9, 2007).

283. Id.

284. See supra text accompanying notes 70-81.

285. See Building a Better Legal Profession, supra note 87. By publicizing firms' self-reported data on "billable hours, pro bono participation, and demographic diversity," Building a Better Legal Profession's unique strategy is to draw attention to the differences between employers. Id. 
almost half her day is spent looking at blogs and the Internet more generally. ${ }^{286}$

She adds,

We are in constant competition with other top firms for the female talent coming out of law schools. If we find out that the firm down the street offers more maternity leave-and this difference is usually highlighted and discussed on some blog-we have to change our policies to stay competitive. ${ }^{287}$

A partner who is active in recruiting describes the impact that blogs have had on her firm:

My firm is starting to recognize that the talent pool is $50 \%$ women, and that you can't be successful in recruiting and retaining the $50 \%$ if your policies are less progressive than other firms. Retention may be an even larger problem than recruiting, since we have to scramble to hire when women leave the firm. We have to respond to the demand to remain competitive, and much of the demand is coming from information shared over the Internet. ${ }^{288}$

A legal recruiting director from a different city has also seen an increase in questions about part-time and reduced hour schedules.

I definitely get more questions about leave policies, part-time paths to partnership, alternative work schedules, and the like. It's a combination of factors. People are taking time before starting law school so they are older when they graduate, and more likely to either have families or be thinking about starting families. But they also have the information they need to ask the right questions. They can go online and see how we have fared in rankings like "Top 50 Law Firms for Women." And if we hadn't made that list, we would have had to change some major things in our firm. ${ }^{289}$

It's not surprising that law students have "the information they need to ask the right questions." In 2007, Flex-Time Lawyers, LLC, Epstein Henry's consulting firm, collaborated with Working Mother Magazine to identify the 50 best law firms for women. ${ }^{290}$ Firms were measured "on a variety of factors including: workforce profile; family-friendly policies; benefits and flexibility; compensation; leadership; and development and advancement of women."291 The rankings were disseminated and discussed throughout the blogosphere. ${ }^{292}$

286. Telephone Interview with Legal Recruiting Director 1 (Nov. 15, 2007); see also Above the Law: A Legal Tabloid, http://www.abovethelaw.com/ (last visited Sept. 17, 2008); American Lawyer on the Web, http://www.americanlawyer.com/ (last visited Sept. 17, 2008); Vault, http://www.vault.com/ (last visited Sept. 17, 2008).

287. Telephone Interview with Legal Recruiting Director 1, supra note 286.

288. Telephone Interview with partner, supra note 142.

289. Telephone Interview with Legal Recruiting Director 2 (Dec. 5, 2007).

290. See Flextime Lawyers, LLC, The 2007 Best Law Firms for Women, http:/ www. flextimelawyers.com/best.asp (last visited Sept. 17, 2008).

291. Id.

292. Telephone Interview with Deborah Epstein Henry, supra note 133. 
Like the 50 Best Law Firms for Women, blogs often feature rankings and tables that provide lawyers with comparative information about legal employers. For example, Above the Law, a popular legal tabloid blog, keeps an up-to-date table of the number of weeks of paid maternity leave offered by various law firms. ${ }^{293}$ Similarly, Building a Better Legal Profession (BBLP) recently released national rankings of law firms based on billable hours, work/life issues, pro bono participation, and demographic diversity. ${ }^{294}$ The highly developed website allows visitors to search the tables by legal market, by specific law firm, and by gender and ethnicity group. The rankings have been so widely disseminated and discussed that both The New York Times and the Los Angeles Times published articles devoted to examining the impact of the rankings. ${ }^{295}$

Recruiters from top law firms woo [Stanford Law School students] with promises of fancy offices, meaningful pro bono work and starting salaries as high as $\$ 160,000$. For [one group of students], that's not nearly enough. They're bent on taming the notoriously workaholic culture of their future profession. ${ }^{296}$

Bloggers are not the first to leverage market pressures to create change. In recent years, advocates like Epstein Henry have worked from the belief that competition among law firms can be "an instrument of change," and have made "work/life balance and women's issues a basis of competition among law firms." 297

While it may not have been the raison d'etre of Ms. JD, Ms. JD and other like-minded blogs have clearly had an impact on law firm policies. One law firm partner told a newspaper reporter, "I don't want to make money off young kids who are working every night and weekend and have no social life, no community life... That person is going to burn out." ${ }^{298}$ His law firm has started to evaluate associates not only on hours but also on skills acquired. "The move has cut the attrition of associates by half and has helped the firm retain

293. Above the Law, Featured Survey Results: Maternity Leave, http:/www.abovethelaw.com/ 2008/02/featured_survey_results_matem_1.php\#more (last visited Sept. 17, 2008).

294. Building a Better Legal Profession (2007 Rankings), http://www.betterlegalprofession.org/ (last visited Sept. 17, 2008).

295. See Adam Liptak, In Students' Eyes, Look-Alike Lawyers Don't Make the Grade, N.Y. TIMES, Oct. 29, 2007, at A10; Molly Selvin, Law Students Make Appeal for Change; A Stanford Group Aims to Improve Associates' Work-Life Balance, L.A. TIMES, Mar. 18, 2008.

296. Selvin, supra note 295.

297. See, e.g., Deborah Epstein Henry, Competition as an Instrument of Change, BALANCE BEAM (Flextime Lawyers LLC, New York, N.Y.), 2005-2006, at 1, available at http://www.flextimelawyers. com/pdf/2005_2006newsletter.pdf. Epstein Henry analogizes her current work on women's issues to various diversity initiatives in the late 1990 s, where "clients [came] together and collectively stated that they are using diversity as a decisive criteria in the selection of outside law firms to represent them." $I d$. at 3 .

298. Selvin, supra note 295. 
female .. . lawyers." ${ }^{299}$ By allowing such relevant and useful information to be exchanged in the marketplace in a nearly costless manner, these blogs have raised the stakes for law firms and created an environment where, in order to attract and retain almost half the "talent pool," firms are forced to revisit ingrained institutional mindsets and practices. Professor Crawford, herself a blogger, describes the impact as "law and economics at its best."

\section{CONCLUSION}

Professor Lani Guinier once described racially-marginalized populations as the "miner's canary"-a reference to the bird that miners carried beside them, whose "more fragile respiratory system would cause them to collapse ... long before humans were affected, thus alerting the miners to danger." 301 I believe that this analogy can be extended: Women lawyers are like the miner's canary. Educated, well-paid, and poised to take full advantage of the legal system, they are a group whose "greater vulnerability to certain [workplace] conditions signals the dangers of those conditions" for all working women and their families. ${ }^{302}$ As Guinier describes, "their distress is a first sign of a danger that threatens us all." $" 303$

Blogging is a useful heuristic for understanding the contemporary challenges faced by women in the workplace and for appreciating the reasons why there may not yet be gender parity in the legal profession. By exploring why women have turned to blogging instead of the law-especially when grappling with issues that are seemingly legal - we discover how gender equity laws, in their current form, are limited in their ability to create equality. We see how institutional biases and male-oriented mindsets loom large, and how the workplace is ripe with "shared conscious and unconscious mental associations about women, men, and leaders." ${ }^{304}$ We see how persistent domestic inequality outside the workplace can directly hinder women's advancement within. We also see, however, how blogging has allowed women to share and obtain

299. Id. It remains to be seen whether advances in recruiting and retaining female talent will translate into any jumps in female partnership numbers, or increases in women's profile in leading legal roles more generally.

300. Telephone Interview with Bridget J. Crawford (Dec. 10, 2007).

301. LANI GUINIER \& Gerald TORRES, THE Miner's CANARY: EnLISTING RaCE, RESISTING POWER, TRANSFORMING DEMOCRACY 11 (2002).

302. Dean Kagan Remarks, supra note 12 (comparing women in the legal profession and Guinier's canaries).

303. GUINIER \& TORRES, supra note 301 , at 11.

304. Alice H. Eagly \& Linda L. Carli, Women and the Labyrinth of Leadership, HARV. BUS. REV. ONLINE VERSION, Sept. 2007, at 63, 65, http://harvardbusinessonline.hbsp.harvard.edu/hbsp/hbr/articles/ article.jsp?articleID=R0709C\&ml_action=get-article\&print=true ("When you put all the pieces together, a new picture emerges for why women don't make it into the C-suite. It's not the glass ceiling, but the sum of many obstacles along the way."). 
information, articulate and communicate their grievances, and gain the strength they need to become stronger and more effective bargainers in the workplace.

Women are socialized to not ask for what they need-we are all part [sic] a pretend game where we are all pretending women are equal. Blogging is allowing us to ask the woman question and raise issues. There's enough self doubt that you will interpret [what happens to you in the workplace] in a way that's more about your weakness than the fact you're a woman. With blogging you can double check [and ask yourself], do you think this is gender? $^{305}$

Blogging has indeed provided women with a new way to be critical of the law from a feminist standpoint.

We are creating our own space, rather than filling a space created for us. Blogging has encouraged women to be critical thinkers and not to bypass things. We are forced to take a look at the stuff around us, and the experiences of others we know, and think about it in terms of gender. ${ }^{306}$

By redefining the ways in which women address contemporary women's issues, blogging represents a new feminist legal method. This method, however, has its roots in a historical movement over one hundred years old. In 1793, after passing the Illinois bar examination with the highest honors, Myra Bradwell was told by the U.S. Supreme Court that "the law of the Creator" and the "divine ordinance" dictated that "the domestic sphere [w]as that which properly belongs to the domain and functions of womanhood." ${ }^{307}$ Bradwell, undaunted by her defeat in the nation's highest court, established the Chicago Legal News, "an extremely prestigious and widely circulated legal newspaper." ${ }^{, 308}$ Using the publication as a vehicle for change, Bradwell successfully advocated for legal reforms in women's rights, child custody, and in the legal system more generally, thus transforming the public's perceptions about women practicing law. ${ }^{309}$ "The true significance of the Chicago Legal News's ... success ... is not that it was an end in and of itself, but that it served as a means, the vehicle by which Myra Bradwell waged successful warfare on so many of the legal and social inequities of her day."310 Almost 140 years later, we see echoes of Bradwell. Confronting a legal system that has yet to achieve true gender equality in the workplace, women lawyers are following Bradwell's example and employing nonlegal methods to advocate for their individual rights in the workplace.

305. Telephone Interview with anonymous blog founding member 2 , supra note 198 .

306. Telephone Interview with Jessica Valenti, supra note 222.

307. Bradwell v. Illinois, 83 U.S. 130, 141 (1872) (Bradley, J., concurring).

308. JANE M. FRIEDMAN, AMERICA'S FIRST WOMAN LAWYER: THE BIOGRAPHY OF MYRA BRADWELL 11 (1993) (describing the life of Myra Bradwell, "America's 'first' woman lawyer ... [who] did more to create rights for women and other legally handicapped persons than did any other woman of her day, or perhaps any day").

309. Id. at 77-91.

310. Id. at 91 . 